\title{
Moral Leadership, Shared Values, Employee Engagement, and Staff Job Performance in the University Value Chain
}

\author{
Eromafuru Edward Godbless
}

Department of Business Administration, Delta State University, Abraka

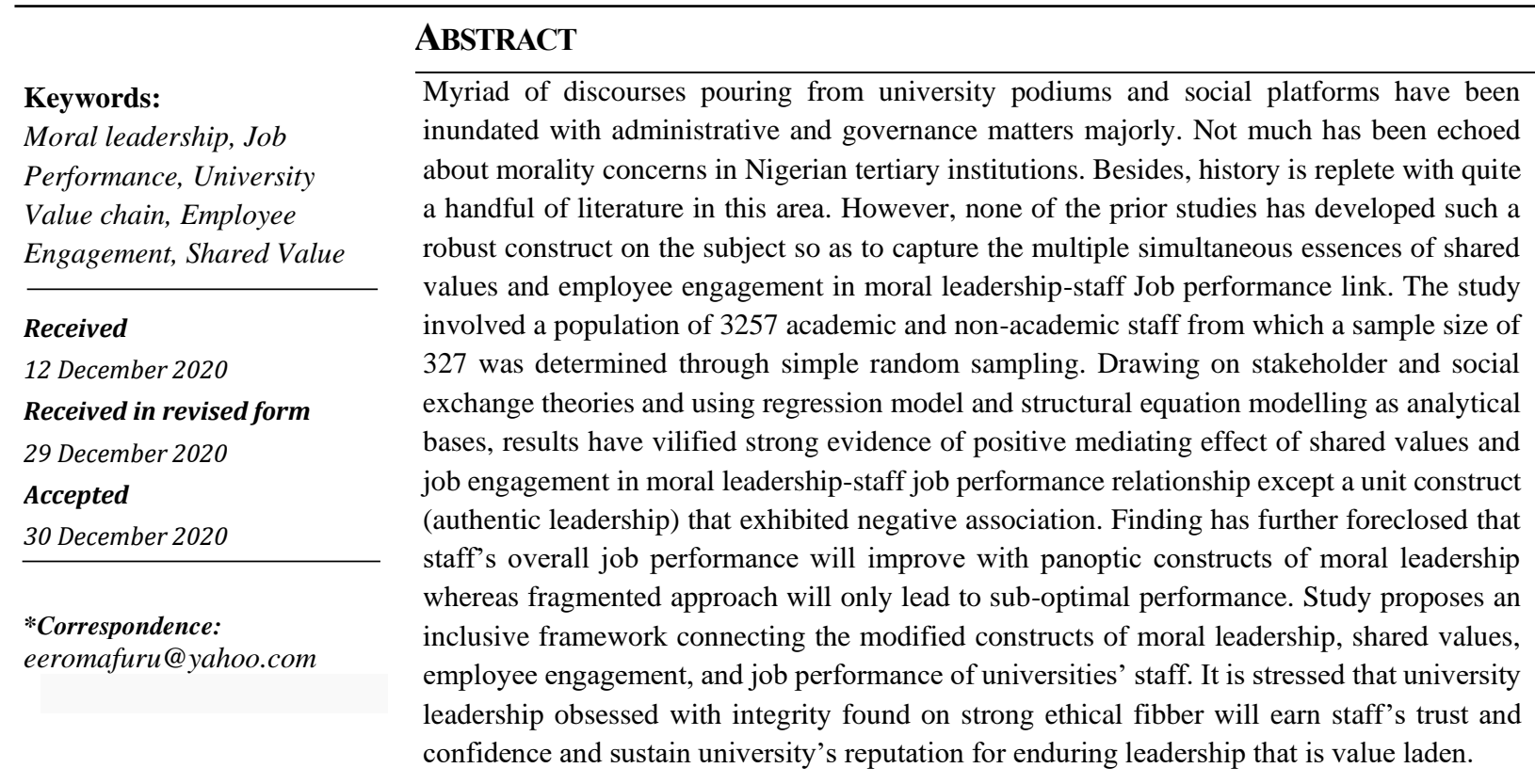

CCIKD Publishing

In a permissive morally debauched world where people take liberty to flaw core-values in the regime of leadership with smeared conscience, would portends a labyrinth of quagmire and disheartening scenarios thus exasperating the daunting challenges of sustaining egalitarian and corrupt-free society (Allen, 2006; Hoyt, Price, \& Poatsy, 2013). A base line assessment of leadership practice in Nigeria as it squarely bears on university's governance reveals that morality has scaled to abysmal low. Social media has been embroiled in heart-wrecking and horrific news about corporate institutions and individuals alleged to have been culpable of ethical malfeasance 
for traversing the course of justice bordering on morality concerns (Bedi, Alpaslan, \& Green, 2015; Yuki, 2010).

Preponderance of challenges ravaging the university system in Sub-Sahara Africa often found their antecedence in flabby leadership beret of moral fibers and unswerving integrity to navigate the institutions through turbulent terrains (Biza \& Mama Irbo, 2020; Liu, 2010). The architects of moral breaches may have exploited lacuna in the existing moral codes and leadership structures that fail to spell out stiff penalty for fragrant moral aberration and compensatory rewards for those toeing the course of integrity. Fragrant aberrations of societal cultural heritage of core values and group norms have been the crux of leadership challenge in Nigeria and diaspora (Casimir, Izueke, \& Nzekwe, 2014; Kempe, 1999).

The above scenario may have triggered renewed curiosities among academia and researchers in the field of moral leadership in the recent times (Casimir et al 2014; Shakeel, Kruyen, \& Thiel 2019). The vulnerability of the university to forces within and outside its cottage, the swelling pressures to compromise on moral issues and the renewed societal demands on the university system to be transparent and earn reputation for deepened integrity and quality service has given credence to potency of the study (De Cremer \& Vandekerckhove, 2017; Gino, 2015; Hegarty \& Moccia, 2018).

Furthermore, the temptation to compromise on moral issues conjugate with the realization that honesty has failed to yield compensable dividends may have spurred many to traverse the course of justice and morality (Carucci, 2016; Mihelic, Lipicnik, \& Tekavecic, 2010). Obsession with moral tenets in our contemporary egalitarian society while warranted is not devoid of perceived bottlenecks and forbearances (Hoseah, 2014). The changed form of industrial life, the unrestrained clamor to amass wealth amid all odds, and the compelling demand by the society for equity and value-added service have pitched most organizations against choosing between the extremes - to be moral or amoral. However, to deliver a winning value proposition; morality must occupy a central page in the University core values (Asiff, Qing, Hwang, \& Shi, 2019; Lambert, Keena, Leone, May, \& Haynes, 2020; Salah, 2016).

A climate of impunity and anarchy will reign supreme in an institutional platform where every participant considers the obligation to be ethical as burden (Carucci, 2016; Lemoine, Hartnell, \& Leroy, 2018; Mackey, Frieder, Brees, \& Martinko, 2017). As plausible as the arguments for moral leadership might seem, the concept of moral leadership is not easily definable (Hegarty \& Moccia, 2018).

By prescribing measures and assemblage of rudiments to rejig moral consciousness among corporate leaders, the study has sought to fill a gap in university governance.

\section{Literature Review}

Quite substantial works on moral leadership and related fields as they impact on performances have been well documented for in-depth theoretical analysis and academic refinements. However, while avalanche of extant literature reviewed addressed the subject from aggregate perspectives only, skeletal studies have been undertaken to examine moral leadership from a more dis-aggregated perspectives.

Dissecting leadership from normative perspective, Sendjaya (2005) has conceived morality as an integral offshoot of leadership and that deontological reasoning provides a sound basis for attractive leadership theories. The author's argument hung on objectivity of universal moral principles as the legitimate basis of a sound understanding of moral leadership. 
Wang and Li (2019) examined the indirect effects of moral leadership on unethical proorganisational behavior. In the study that included 161 MBA students and 205 enterprise employees in china, and using structural equation modeling, the authors found identification with supervisors, taking responsibility, and moral courage as mediating relationship between moral leadership and unethical pro-organisational behavior.

In their study involving 395 Chinese employees, Bao and $\mathrm{Li}$ (2019) found value congruence and leader-member exchange mediating the effect of moral leadership on followers' positive work behaviors. Also, in the empirical work involving 204 employees across different business organisations, and using structural equation modelling, Engelbrecht, Gardielle, and Mahembe (2017) affirmed positive mediating effect of ethical leadership in leader integrity-work engagement relationship. In similar vein, concerted efforts have been made by scholars such as Changsuk, Jianhong, Roman, Mark, Haney, and Mingu (2017) to review empirical findings from ethical leadership literature using a framework comprising the antecedents, mediations, moderators, and outcomes of ethical leadership from which a set of interesting research opportunities can be explored and for future research endeavors. Gauging social learning theory from multi-level perspective, Bao, Lin, and Liu (2017) have proposed a theoretical underpinning that explores both team and individual dimension mechanisms as mediators of the effects of ethical leadership on employee voice in China. This study apart from being restricted to three entertainment and service companies in China revolved around a dimension of moral leadership only.

However, the current research, apart from x-raying moral behaviors and practices among university executives, has addressed the subject from a more disaggregated and holistic standpoints by linking multiple dimensions of moral leadership to job performance of university staff.

The research by Asiff et al. (2019) though has impressively illustrated how affective commitment and work engagement can mediate between ethical leadership and creativity, there is however a missing link in realizing that employees must first see themselves as organizational key active participants before taking action to bolster efforts (commitment) in advancing the group and individual cause, the void which the present study sought to fill.

Other studies have attempted to theorize the concept through assemblage of theories, principles and processes underpinning the practice over time (Kraatz, Flores, \& Chandler, 2020; Solinger, Jansen, \& Cornelissen, 2020). Servant leadership is an evolving and enduring leadership practice that is gaining increasing momentum in the 21st century (Spears, 1996; Russell, 2001). Nonetheless, literatures on servant leadership have failed to address the moral-laden angle of leader-follower relationship.

In this study, the author stresses mutuality of intent and purpose in enacting organisational values and shared meaning that reinforce commitment to sense of identity and restoration of human dignity in the social exchange platform. Furthermore, in what may appear to be a swift shift from extant literatures in this area, and by adapting different organizational context, the author of this work is keen in investigating the connection between moral leadership and job performance with the mediating links of shared values and job engagement.

\section{Theoretical Framework}

\section{Stake Holder Theory}

Stakeholder theory addresses issues of values, morals and ethics in managing relationships between organizations and stakeholders or organisational constituents including customers, suppliers, financiers, directors, shareholders, and employees. Stakeholder theory was first conceptualized by 
organisational theorist Mitroff in his book, "Stakeholders of the Organizational Mind" published in (Mitroff, 1983). This was followed by an article released same year in the Management Review by R. Edward Freeman, a Californian philosopher and professor of Business Administration. After series of rigorous research and discussions at Stanford Research Institute, he went on to publish his book, "Strategic Management: A Stakeholder Approach" (Freeman, 1984).

In what may be surmised as apparent mark of affirmation of Edward Freeman's stakeholder theory, Donalson and Peterson had in 1995 argued that stakeholder theory has descriptive, instrumental, and normative aspects that are mutually supportive (Donalson \& Peterson, 1995) The three generic terms are presumably the characteristics and behaviors of corporations or host organisations that allow them to describe, evaluate, and align their desires to maximize economic gains with their obligations to act in the best interest of the stakeholders by upholding core values and group norms.

Implicit in the theory is the underlying assumption that for organization to be successful, it must add value to the stakeholders whether by way of service delivery, relationship building, human capital development or inclusive people-oriented programmes.

The university institution just like any other social entity is an open system with multiple subsystems, functioning within the ambit of larger environment. At the top echelon of administration are the visitors, council members, and management staff. At the heart of administration, policy formulation and strategic decision making are the Vice-Chancellors franked by their deputies, registrars, bursars, librarian, and provosts. The Deans, Directors, Heads of Departments occupy the middle layers in the hierarchy. They breakdown and execute the decision reached at the top level and push them down the chain for further action by the lower cadres in the chain. At the lower pyramid of the hierarchical structure are the teaching and non-teaching staff, supervisors, students, and rank and file.

The stakeholders in this sense and for the purpose of the study are the visitors to the university including the state Governors, the commissioners for higher education, pro-chancellors, chairman of council, management team, the university staff, students, host communities, government agencies, financiers, and suppliers. Each of the claimants has one stake or the other to protect and oftentimes their interests hardly converge. In exchange for their contributions to the university's well-being, employees seek reciprocation in the forms of quality leadership, trust, transparency, provision of social welfare schemes, staff development, job security and equitable reward.

\section{Social Exchange Theory}

The theory of social exchange is with the contention that social behavior is the result of an exchange process, the purpose for which to maximize benefits and minimize costs (Kendra, 2020). The notion of social exchange theory was first coined by George Homans in his published article "Social Behavior as Exchange". Homans' framework blended theories from behavioral sciences and basic economics. The philosophical basis for the theory is the understanding that a relationship between two persons is a double-edged engagement created and rationalized through the process of costbenefit analysis (Homans, 1961). At the heart of the theory is the notion that relationship that earns approval from another person is more likely to be repeated whereas those disapproved are unlikely to be repeated. The main trust of the theory is assumption about human nature and their relationships.

Naturally and from their rational inclinations, humans are assumed to always want to seek out rewards and avoid punishments. It is the expectation of humans that the ensuing interactions will 
translate to maximum benefit and minima loss (Crossman, 2020). As expected, individuals would estimate potential economic values (benefits and risk) of social relationships and would likely quit relationships that would result in higher economic loss. The value of the benefits and costs of relationships are critical determinants to defining relationships. The uniqueness of the theory is inferred by the appreciation that it does not necessarily measure relationships on emotional metrics, rather its systematic processes rely on mathematics and logic to determine balance within a relationship. To predict the behavior of individuals in the social exchange, Crossman (2020) recommended the following formula: Behavior (profits) = Rewards of interaction - Costs of interaction. By application, if reward for an action exceeds the punishment, then the action is likely to occur. The reverse is also true.

What parallel is social exchange theory to this study? In any social system, relationships are often defined in terms of give and take with no party completely losing out or benefiting at the expense of the other. The university staff usually would build anticipations for economic benefits in terms of equitable pay, unbiased promotion, social well-fare packages, job security, unhindered career progression and work-life balance. These are what they often expect in exchange for the use of their time, their commitment, opportunity cost, haphazard work environment, loyalty, meritorious services and temporary dis-connect from family. On the other hand, staff would build apprehension for management policies and actions that humiliate, threaten, and deprive individual rights to self-determination and job security. The expectation that management will live up to its obligation in dispensing justice and improving staff well-being will re-invoke staff's discretionary positive attitude to work while a negative perception of same will breed resentments, ill-feelings, and staff negative attitude to work. To maximize the value of the exchange management and staff are to minimize actions that undermine the group effectiveness while maximizing actions and behavior that preserve the collective stake of the group.

\section{Conceptual Framework and Hypotheses Development}

The author modified and adapted the leadership constructs refined and developed by Lemoine et al. (2018). Earlier, Baron, Pettit, and Slote (1997) had proposed a three-model framework of normative morality. In their original conceptualization, the trio of Lemoine et al (2018) polarized moral leadership as a construct of three building brocks - ethical leadership, servant leadership and authentic leadership. Building on these constructs, the study has incorporated additional two constructs namely, value-reward leadership and inspirational leadership. The author considered value-reward leadership and inspirational leadership as compatibly reinforcing in shaping and inculcating university's core values in staff and management. Figure 1 illustrates the conceptual framework of the study. A glance at the model depicts employee engagement and shared value mediating relationship between moral leadership constructs (value-reward leadership, servant leadership; ethical leadership, inspirational leadership, authentic leadership) and dimensions of staff job performance (staff productivity, job commitment, confidence building, job retention, employee motivation and confidence building). 


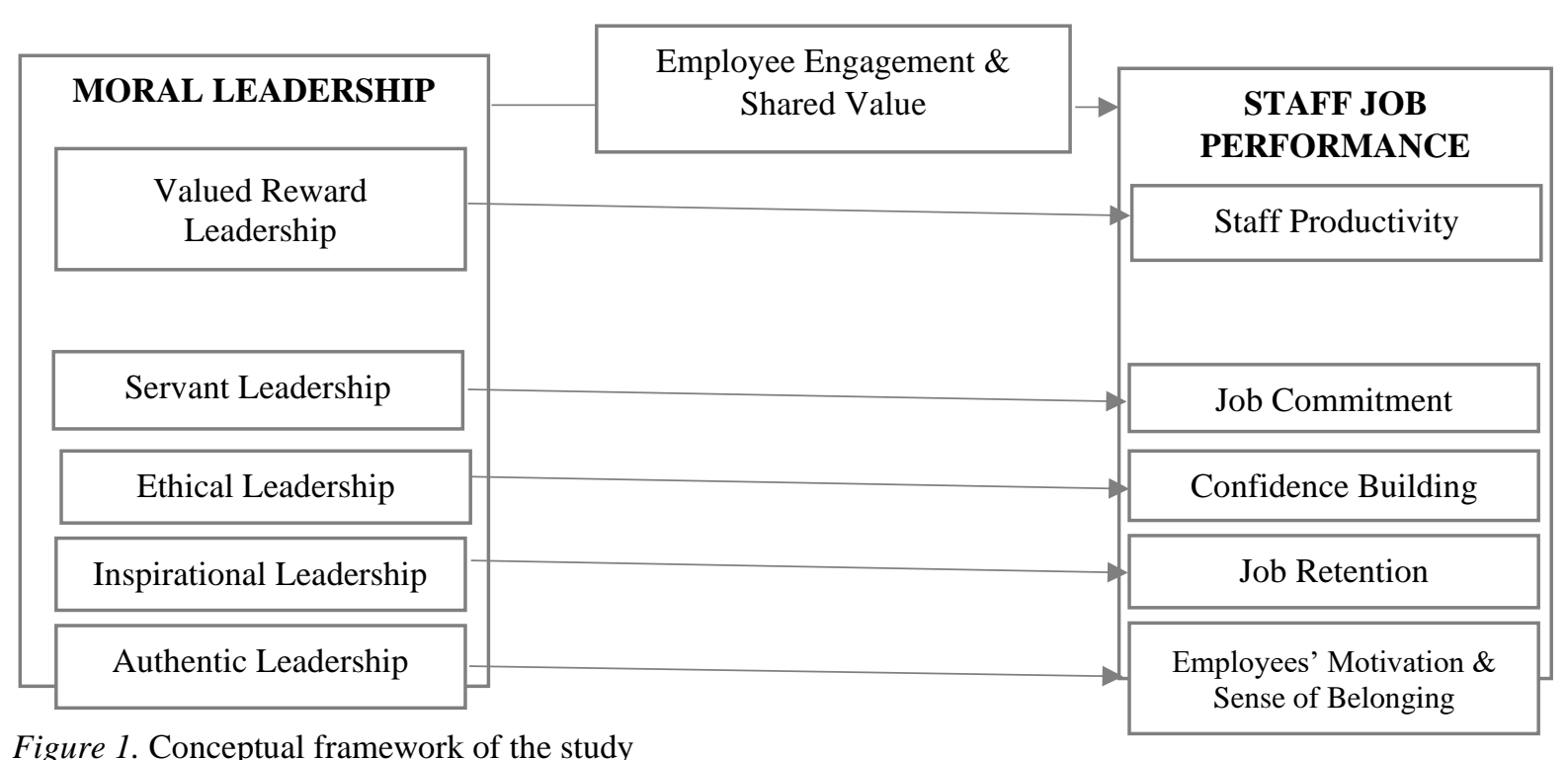

Figure 1. Conceptual framework of the study

\section{Hypotheses}

1. Fair reward practices do not correlate with the productivity of the university staff employees.

2. Servant leadership does not significantly affect the level of job commitment among university staff

3. Ethical leadership will not raise the level of trust and confidence building among university staff.

4. Inspirational leadership does not significantly influence the level of job retention among staff of Nigerian universities.

5. Authentic leadership does not increase employee' motivation and sense of belonging.

6. Employee engagement does not moderate the effects of moral leadership on job performance of university staff.

\section{Model Specification}

SJPERF $\quad=\mathrm{f}($ MLSHIP $)$

\section{Eqn. 1}

\begin{tabular}{|c|c|c|}
\hline MLSHIP & $=$ & (VLSHIP, SLSHIP, ELSHIP, ILSHIP and ALSHIP) ...... Eqn. 2 \\
\hline SJPERF & & (STAFPV, JOBCOM, TRCONB, JOBRET and MOTSBL) ....Eqn. 3 \\
\hline
\end{tabular}

From dimensions of Moral Leadership in equation 1 and the measures of Staff Job Performance in equation 2 , we come up with equation $4-8$, representing models 1-5.

Model 1: STAFPV $=\alpha_{1}+\beta_{1}$ VLSHIP $+\mathrm{U}_{1}$

Eqn. 4

Model 2: JOBCOM $=\alpha_{2}+\beta_{2}$ SLSHIP $+\mathrm{U}_{2}$

Model 3: TRCONB $=\alpha_{3}+\beta_{3}$ ELSHIP $+\mathrm{U}_{3}$

Model 4: JOBRET $=\alpha_{4}+\beta_{4}$ ILSHIP $+\mathrm{U}_{4}$

Model 5: MOTSBL $=\alpha_{5}+\beta_{5}$ ALSHIP $+\mathrm{U}_{5}$

Model 6: Moderating role of Shared Values, Employee Engagement in Moral Leadership-Job performance Links 


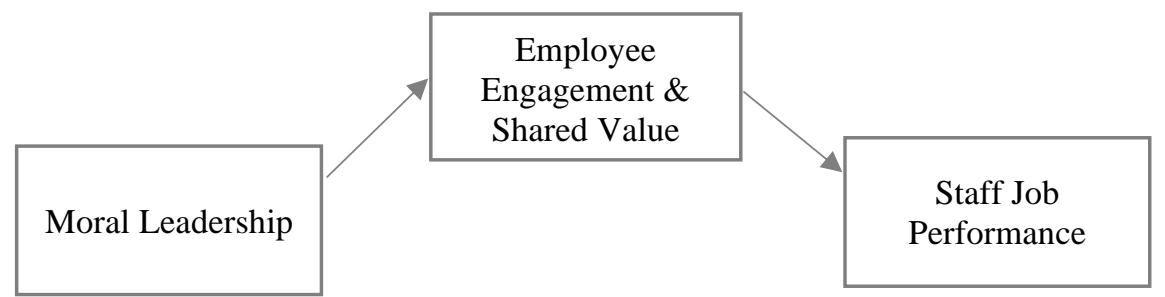

Figure 2. showing moral leadership, staffs job performance and mediations.

Source: Author's construct (2020)

Note:

$\begin{array}{lll}\text { SJPERF } & = & \text { Staff Job Performance } \\ \text { MLSHIP } & = & \text { Moral Leadership } \\ \text { EENGSV } & = & \text { Employee engagement and Shared value } \\ \text { VLSHIP } & = & \text { Value-Reward Leadership } \\ \text { SLSHIP } & = & \text { Servant Leadership } \\ \text { ELSHIP } & = & \text { Ethical Leadership } \\ \text { ILSHIP } & = & \text { Inspirational Leadership } \\ \text { ALSHIP } & = & \text { Authentic Leadership } \\ \text { STAFPV } & = & \text { Staff Productivity } \\ \text { JOBCOM } & = & \text { Job Commitment } \\ \text { TRCONB } & = & \text { Trust and Confidence Building } \\ \text { JOBRET } & = & \text { Job Retention } \\ \text { MOTSBL } & = & \text { Motivation and Sense of Belonging } \\ \text { EMPENG } & = & \text { Employee engagement } \\ \text { SHDVAL } & = & \text { Shared value }\end{array}$

\section{Method}

The unit of analyses consists of Academic Staff in the range ranks of Assistance Lecturer to Senior Lecturer; and Non-Academic Staff in the range levels of Grade Level 6 to grade level 14 in the selected twenty-eight (28) out of thirty-eight (38) State Universities approved by the Nigerian Universities Commission (NUC) up to 2019. The universities are those that host Faculty of Management or Social Sciences and included a target population of 3,257 from which a sample size of 357 was selected. Preference was made for a cross-sectional research design in view of the dynamic and multi-faceted nature of the study. Due to the covid-19 scare, an online survey was employed in eliciting responses from sampled university staff in an anonymous and confidential setting. Adoption was made of simple random probability sampling method to give equal chance for each member of the population to be selected. The procedure for deriving the sample size for the study is followed as hereunder using Taro Yamane formula:

$$
\begin{aligned}
& \mathrm{n}=\frac{\mathrm{N}}{1+\mathrm{N}(\mathrm{e})^{2}} \\
& \mathrm{n}=\underline{3,257} \\
& 1+3257(0.05)^{2} \mathrm{n}=357 .
\end{aligned}
$$

With the above result, a total of three hundred and fifty-seven (357) set of questionnaires were administered to the respondents, with a 5-point Likert scale ranging from strongly agree (5), agree 
(4), disagree (3), strongly disagree (2) and Undecided (1); a total of three hundred and four (304) were returned, representing $85 \%$ return rate while 300 was used for analysis. The research instrument was tested for internal consistency by conducting a pilot study involving $10 \%$ of the sample size with the Cronbach alpha-based test. The result of reliability test showed an acceptable Cronbach alpha score above .70 for all the constructs and a mean value of .94 as illustrated in Table 1.

Table 1

Reliability Test of Research Instrument Used in the Study

\begin{tabular}{|c|c|c|c|c|c|c|c|}
\hline Item & Unit & Observation & Sign & $\begin{array}{l}\text { Item-test } \\
\text { correlation }\end{array}$ & $\begin{array}{l}\text { Item-test } \\
\text { correlation }\end{array}$ & $\begin{array}{c}\text { Average } \\
\text { inter-item } \\
\text { covariance }\end{array}$ & Alpha \\
\hline Value-reward leadership & 1 & 30 & + & .85 & .82 & .21 & .94 \\
\hline Staff Productivity & 1 & 30 & + & .84 & .81 & .21 & .94 \\
\hline Servant Leadership & 1 & 30 & + & .75 & .70 & .21 & .94 \\
\hline Job Commitment & 1 & 30 & + & .63 & .56 & .22 & .95 \\
\hline Ethical Leadership & 1 & 30 & + & .78 & .73 & .21 & .94 \\
\hline $\begin{array}{l}\text { Trust and Confidence } \\
\text { Building }\end{array}$ & 1 & 30 & + & .86 & .83 & .21 & .94 \\
\hline Inspirational Leadership & 1 & 30 & + & .80 & .75 & .21 & .94 \\
\hline Job retention & 1 & 30 & + & .85 & .82 & .21 & .94 \\
\hline Authentic leadership & 1 & 30 & + & .84 & .81 & .21 & .94 \\
\hline $\begin{array}{l}\text { Motivation and Sense of } \\
\text { Belonging }\end{array}$ & 1 & 30 & + & .75 & .70 & .21 & .94 \\
\hline Empowerment & 1 & 30 & + & .78 & .73 & .21 & .94 \\
\hline Shared value & 1 & 30 & + & .86 & .83 & .21 & .94 \\
\hline Test scale & 1 & & & & & .21 & .94 \\
\hline
\end{tabular}

\section{Results}

\section{Descriptive Statistics}

The descriptive statistics depicts the mean value above 4.0 and maximum of 5 scores. The level of agreement of respondents was judged by the average mean above 4.0 which explains the high respondent's rate in the respondent's pattern (see also Appendix 2). Table 2 below clearly illustrates the mean response pattern among the staff across all constructs.

Table 2

Descriptive Statistics Showing the Mean Response Rates among Staff Across All Constructs

\begin{tabular}{|c|c|c|c|c|c|c|}
\hline Variable & unit & Mean & $\mathrm{pS} \theta$ & $\max$ & $\min$ & $\mathrm{N}$ \\
\hline Value-reward leadership & 1 & 4.28 & 4 & 5 & 1 & 300 \\
\hline Staff Productivity & 1 & 4.29 & 4 & 5 & 1 & 300 \\
\hline Servant Leadership & 1 & 4.37 & 4 & 5 & 1 & 300 \\
\hline Job Commitment & 1 & 4.33 & 4 & 5 & 1 & 300 \\
\hline Ethical Leadership & 1 & 4.30 & 4 & 5 & 1 & 300 \\
\hline Trust and Confidence Building & 1 & 4.31 & 4 & 5 & 1 & 300 \\
\hline Inspirational Leadership & 1 & 4.29 & 4 & 5 & 1 & 300 \\
\hline Job retention & 1 & 4.28 & 4 & 5 & 1 & 300 \\
\hline Authentic leadership & 1 & 4.29 & 4 & 5 & 1 & 300 \\
\hline Motivation and Sense of Belonging & 1 & 4.37 & 4 & 5 & 1 & 300 \\
\hline Empowerment & 1 & 4.30 & 4 & 5 & 1 & 300 \\
\hline Shared value & 1 & 4.31 & 4 & 5 & 1 & 300 \\
\hline
\end{tabular}




\section{Normality test}

The result of the Jacque Bera normality test in Table 3 showed that all variables are normally distributed at $1 \%$ level of significance. Any suggestions furnished, to a very large extent would therefore represent the characteristics of the true population of study.

Table 3

Result of Normality Test

\begin{tabular}{lccccc}
\hline Variable & Observation & Pr(skewness) & Pr(kurtosis) & Adj chi $^{2}(2)$ & ${\text { Prob }>\text { chi }^{2}}^{2}$ \\
\hline Value-reward leadership & 300 & .23 & .00 & 8.11 & .01 \\
Staff Productivity & 300 & .25 & .00 & 8.34 & .01 \\
Servant Leadership & 300 & .06 & .00 & .00 & .001 \\
Job Commitment & 300 & .00 & .00 & 17.09 & .001 \\
Ethical Leadership & 300 & .08 & .00 & 11.24 & .001 \\
Trust and Confidence Building & 300 & .13 & .00 & 10.41 & .001 \\
Inspirational Leadership & 300 & .15 & .00 & 9.18 & .01 \\
Job retention & 300 & .23 & .00 & 8.11 & .01 \\
Authentic leadership & 300 & .25 & .00 & 8.34 & .01 \\
Motivation and Sense of Belonging & 300 & .06 & .00 & 16.20 & .001 \\
Empowerment & 300 & .08 & .00 & 11.24 & .001 \\
Shared value & 300 & .11 & .00 & 10.81 & .001 \\
\hline
\end{tabular}

\section{Correlation Matrix}

The correlation test analysis (see Table 4) reveals positive correlation across all constructs implying that dimensions of moral leadership -valued-reward leadership, servant leadership, ethical leadership, inspirational leadership; and the mediating variables-shared values and employee engagement, were found to positively correlate except the dimension of independent variable (authentic leadership) which is negatively correlated.

Table 4

Results of Correlation Test Analysis

\begin{tabular}{|c|c|c|c|c|c|c|c|c|c|c|c|c|}
\hline Variable & 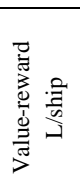 & 莬 & 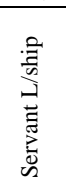 & 융 & 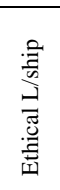 & 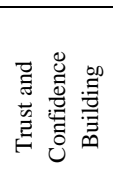 & 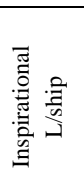 & 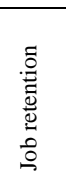 & 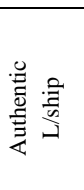 & 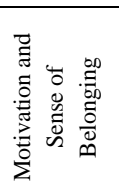 & 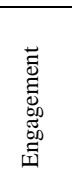 & 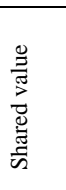 \\
\hline $\begin{array}{l}\text { Value-reward } \\
\text { leadership }\end{array}$ & 1.00 & & & & & & & & & & & \\
\hline $\begin{array}{l}\text { Staff } \\
\text { Productivity }\end{array}$ & .66 & 1.00 & & & & & & & & & & \\
\hline $\begin{array}{l}\text { Servant } \\
\text { Leadership }\end{array}$ & .51 & .52 & 1.00 & & & & & & & & & \\
\hline $\begin{array}{l}\text { Job } \\
\text { Commitment }\end{array}$ & .48 & .46 & .44 & 1.00 & & & & & & & & \\
\hline $\begin{array}{l}\text { Ethical } \\
\text { Leadership }\end{array}$ & .72 & .47 & .50 & .47 & 1.00 & & & & & & & \\
\hline $\begin{array}{l}\text { Trust and } \\
\text { Confidence } \\
\text { Building }\end{array}$ & .62 & .82 & .58 & .49 & .55 & 1.00 & & & & & & \\
\hline $\begin{array}{l}\text { Inspirational } \\
\text { Leadership }\end{array}$ & .65 & .69 & .59 & .41 & .53 & .67 & 1.00 & & & & & \\
\hline Job retention & .50 & .66 & .51 & .48 & .72 & .67 & .65 & 1.00 & & & & \\
\hline $\begin{array}{l}\text { Authentic } \\
\text { leadership }\end{array}$ & .66 & .00 & .52 & .16 & .47 & .12 & .29 & .06 & 1.00 & & & \\
\hline $\begin{array}{l}\text { Motivation } \\
\text { and Sense of } \\
\text { Belonging }\end{array}$ & .51 & .52 & .45 & .44 & .50 & .58 & .58 & .51 & .52 & 1.00 & & \\
\hline Empowerment & .72 & .47 & .50 & .47 & .48 & .55 & .53 & .72 & .47 & .50 & 1.00 & \\
\hline Shared value & .63 & .82 & .57 & .49 & .54 & .99 & .68 & .63 & .82 & .57 & .54 & 1.00 \\
\hline
\end{tabular}




\section{Testing of Hypotheses}

\section{Model 1}

$\mathrm{HO}_{1}$ : Value-reward leadership practices do not correlate with the productivity of the university staff employees.

As shown in Table 5, the regression result for model 1 with $(\beta=.66)$ indicates existence of close ties between value-reward leadership practice and productivity of the university staff employees, thus leading to rejection of the null hypothesis $\left(\mathrm{H}_{1}\right)$ and acceptance of alternate $\left(\mathrm{HA}_{1}\right)$. The adjusted $\mathrm{R}^{2}$ value of .44 shows that $44 \%$ of the systematic variations in productivity of the university staff employees is explained by value-reward leadership practice. Furthermore, the Fstatistic of 241.73 is statistically significant at $1 \%(.01)$ given $p<.01$, a confirmation that value reward leadership is statistically significant and a valid predictor of staff level of productivity.

Table 5

Results of Regression Test Model 1

\begin{tabular}{|c|c|c|c|c|c|c|}
\hline Source & $S S$ & $d f$ & $M S$ & & No. of Observation & $=300$ \\
\hline Model & 45.76 & 1 & 45.76 & & $\mathrm{~F}(1,298)$ & $=241.73$ \\
\hline Residual & 56.42 & 298 & .189 & & Prob $>F$ & $=.001$ \\
\hline \multirow[t]{3}{*}{ Total } & 102.18 & 299 & .34 & & $\mathrm{R}^{2}$ & $=.44$ \\
\hline & & & & & $\operatorname{Adj} R^{2}$ & $=.44$ \\
\hline & & & & & Root MSE & $=.43$ \\
\hline Staf-prod & $\beta$ & Std. Err. & $t$ & $p>|\mathrm{t}|$ & {$[95 \%$} & Interval] \\
\hline Value & .66 & .04 & 15.55 & .001 & .58 & .74 \\
\hline \multicolumn{7}{|l|}{ L/ship } \\
\hline cons & 1.44 & .18 & 7.78 & .001 & 1.07 & 1.80 \\
\hline
\end{tabular}

\section{Model 2}

$\mathrm{HO}_{2}$ : Servant leadership does not significantly affect the level of job commitment among university staff.

Regression result for Model 2 has produced the Beta value of $(\beta=.53)$ an affirmation of significant positive relationship between servant leadership and the level of job commitment among university staff signaling the null hypothesis $\left(\mathrm{HO}_{2}\right)$ being rejected and the alternate hypothesis $\left(\mathrm{HA}_{2}\right)$ accepted. The adjusted $\mathrm{R}^{2}$ value of .27 shows that $27 \%$ of the systematic variations in the level of job commitment among university staff is explained by servant leadership. The F-ratio of 155.70 with associated $\mathrm{P}$-value is evidence that the linear regression model on the overall is statistically significant at $1 \%(0.01)$ level.

Table 6

Results of Regression Test Model 2

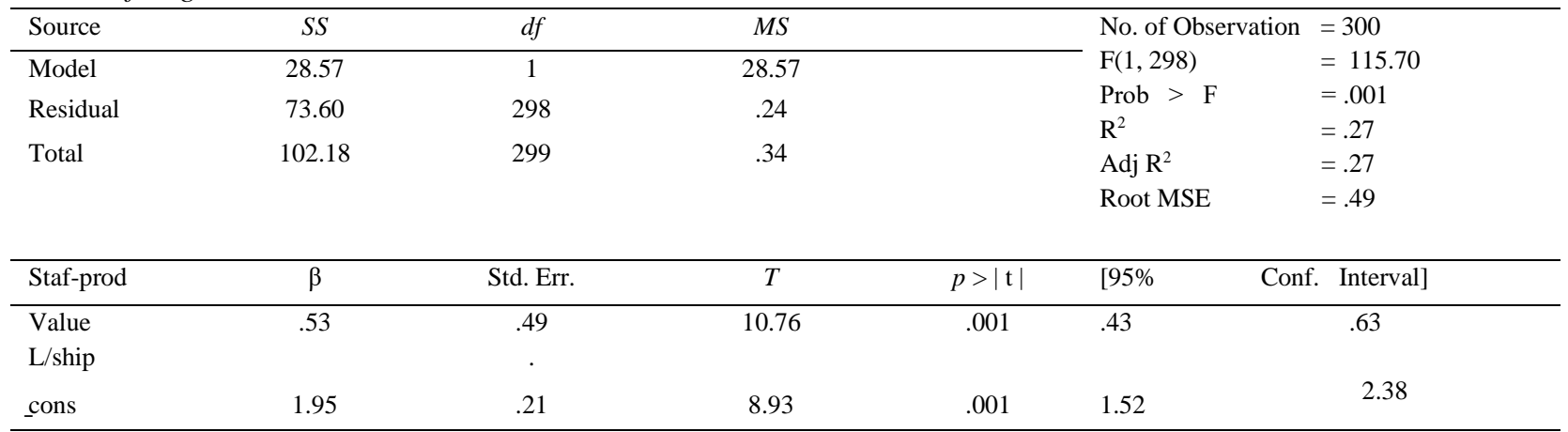




\section{Model 3}

$\mathrm{HO}_{3}$ : Ethical leadership will not raise the level of trust and confidence building among university staff.

The test result (see Table 7) for hypothesis three (3) has shown significant relationship between ethical leadership and level of trust and confidence building among university staff. This is confirmed from the regression result that yields $(\beta=.49, p=.001)$ leading to the rejection of the null hypothesis $\left(\mathrm{H}_{3}\right)$ and acceptance of the alternate hypothesis $3\left(\mathrm{HA}_{3}\right)$ thus affirming significant relationship between ethical leadership and level of trust and confidence building among university staff. The adjusted $\mathrm{R}^{2}$ value of .21 is an attestation that $21 \%$ of the change in the level of trust and confidence building among university staff is explained by ethical leadership. Finally, the F-statistic of 85.22 and P-value of .001 is an affirmation that the linear regression model on the overall is statistically significant at $1 \%$ level.

Table 7

Results of Regression Test Model 3

\begin{tabular}{|c|c|c|c|c|c|c|}
\hline Source & $S S$ & $d f$ & $M S$ & & \multirow{2}{*}{$\begin{array}{l}\text { No. of Observation } \\
F(1,298)\end{array}$} & \multirow{2}{*}{$\begin{array}{l}=300 \\
=85.22\end{array}$} \\
\hline Model & 26.38 & 1 & 26.38 & & & \\
\hline Residual & 92.27 & 298 & .30 & & Prob $>F$ & $=.001$ \\
\hline Total & 118.66 & 299 & .39 & & Adi $R^{2}$ & $\begin{array}{l}-.22 \\
=21\end{array}$ \\
\hline & & & & & Root MSE & $=.55$ \\
\hline Staf-prod & $\beta$ & Std. Err. & $t$ & $|p>| \mathrm{t} \mid$ & {$[95 \%$} & Conf. Interval] \\
\hline Value & .49 & .05 & 9.23 & .001 & .38 & .60 \\
\hline L/ship & & . & & & & \\
\hline cons & 2.20 & .23 & 9.45 & .001 & 1.74 & 2.66 \\
\hline
\end{tabular}

\section{Model 4}

$\mathrm{HO}_{4}$ : Inspirational leadership does not significantly influence the level of job retention among staff of Nigerian universities.

On the relationship between inspirational leadership and influence on the level of job retention among staff of Nigerian universities, the test result (Table 8 ) for model (4) with $(\beta=.67, p=.001)$ has revealed significant relationship between them. With this outcome, the null hypothesis $\left(\mathrm{H}_{4}\right)$ is rejected while the alternate hypothesis accepted. Again, with the adjusted $\mathrm{R}^{2}$ value of 0.45 , the implication is that $45 \%$ of the systematic variations in the level of job retention among staff of Nigerian universities are explained by Inspirational leadership. The F-statistic of 251.72 and its associated P-value of .001 , point at the regression model on the overall being statistically significant at $1 \%$ level.

Table 8

Results of Regression Test Model 4

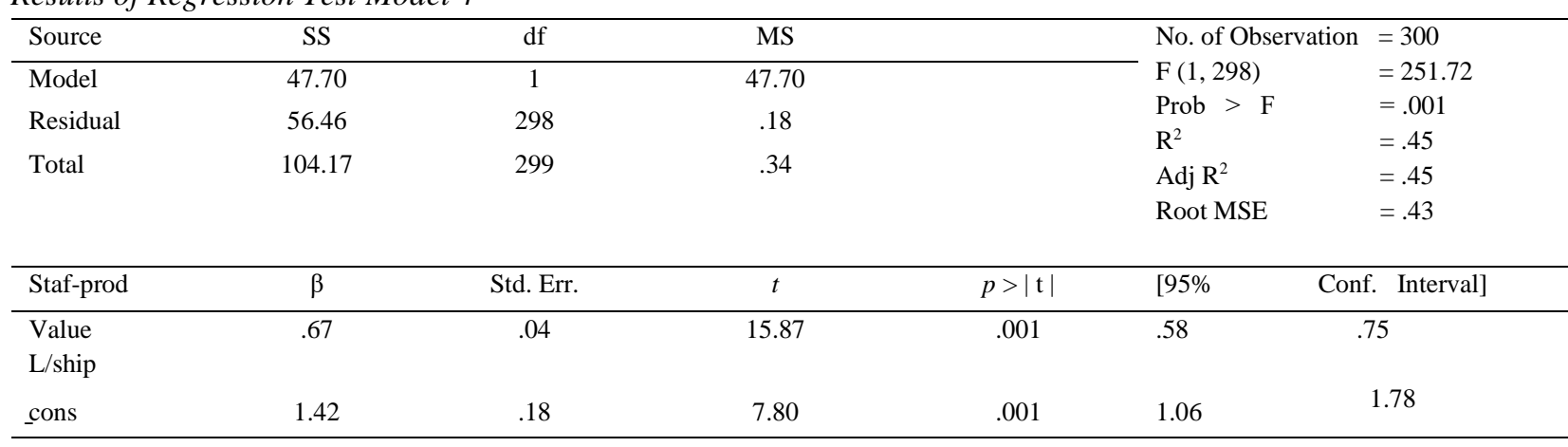




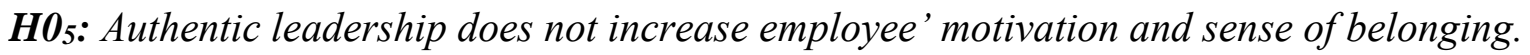

Test regression result from Table 9 that produces the Beta value of $(\beta=.19, p=.05)$ is an indication that Authentic leadership has a weak contribution that is not significant to employee' motivation and sense of belonging. Consequent upon this, the null hypothesis ( $\left.\mathrm{H}_{5}\right)$ is accepted and the alternate hypothesis $\left(\mathrm{H}_{5}\right)$ rejected, suggesting that authentic leadership has no significant relationship with employee' motivation and sense of belonging among university staff. The adjusted $\mathrm{R}^{2}$ value of .01 shows that $1 \%$ of the systematic variations in employee' motivation and sense of belonging among university staff is explained by authentic leadership. The F-ratio of 115.70 and corresponding P-value of .001 implies that the linear regression model on the overall is statistically significant at $1 \%$ level.

Table 5

Results of Regression Test Model 5

\begin{tabular}{|c|c|c|c|c|c|c|}
\hline Source & $S S$ & $d f$ & $M S$ & & \multirow{2}{*}{$\begin{array}{l}\text { No. of observation } \\
F(1,298)\end{array}$} & \multirow{2}{*}{$\begin{array}{l}=300 \\
=115.70\end{array}$} \\
\hline Model & 27.94 & 1 & 27.94 & & & \\
\hline Residual & 71.98 & 298 & .24 & & Prob $>F$ & $=.001$ \\
\hline Total & 99.93 & 299 & .33 & & Adi $R^{2}$ & $=.01$ \\
\hline & & & & & Root MSE & $=.49$ \\
\hline Staf-prod & $\beta$ & Std. Err. & $t$ & $p>|\mathrm{t}|$ & {$[95 \%$} & Conf. Interval] \\
\hline Value & .19 & .04 & 10.76 & .05 & .42 & .61 \\
\hline L/ship & & & & & & \\
\hline cons & 2.12 & .21 & 10.09 & .001 & 1.71 & 2.53 \\
\hline
\end{tabular}

\section{Model 6}

H06: shared values and employee engagement do not mediate the effects of moral leadership on job performance of university staff.

The author employs structural equation modelling (SEM) to test the cumulative mediating effect of shared values and employee engagement in moral leadership and job performance link. From SEM path analysis (see Figure 3), we can visualize the direct path from moral leadership to job performance (.02) and the indirect part from employee engagement to job performance being (.68). we can then visualize remarkable improvement between shared value and Employee engagement and staff job performance (.68) as compared to Moral Leadership and staff job performance (.02), thus implying that shared values and employee engagement significantly mediate relationship between moral leadership and job performance of university staff (Compare Appendix 1). 


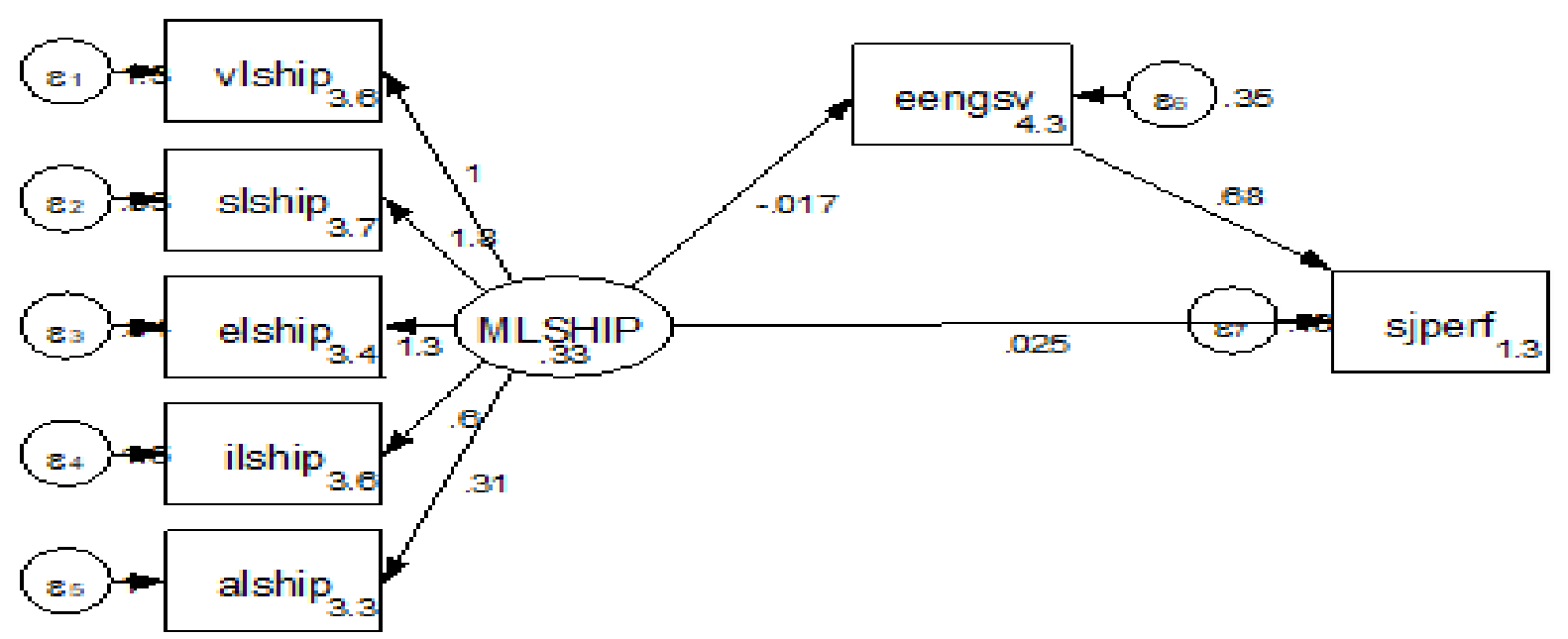

Figure 3. Structural Equation Modelling Analysis paths

\section{Discussion}

\section{Value Reward Leadership and Staff Productivity}

The regression result for model 1 (see Table 5) has implicated that value-reward leadership practice significantly relates to productivity of the university's academic and non-academic staffs. Building on that premise it stands to affirm how enforcing integrative and coherent reward system, revolving around equity, justice, and fair play is critical to unleashing staff's creative and innovative thinking on one hand (Li, Chen, \& Lai, 2017; Al Darmaki, Omar, \& Wan Ismail, 2019) and the integrity and oneness of the group on the other hand (Fudge \& Schlacter, 1999).

It is further gathered that employees from their subjective assessments often develop quite unimaginable set of beliefs and assumptions about the fairness of organisational reward practices which they envisage to be competitively adequate and performance reinvigorating in consonance with the findings of Ajmal, Bashir, Abrar, Khan, and Saqib (2015). One un-denying fact is the notion that reward must fill a particular need in order to justify its essence. The intention and motive of administrator of reward matter most to employees than the value of the reward itself.

The study strongly argued that reward should be seen in the light of re-affirming organization's belief and confidence in the worth of the employee as well as energizing them to bring to bear their discretionary and creative thrust on the path to accomplishing organisational missions and goals. When reward is criminalized or designed with ulterior motive in breach of moral tenets, it becomes hard to assess the integrity and efficacy of the reward more so as it relates to job performance. This affirmation support findings of Kurland (1995). To harness their overall impacts, staffs were of the view that rewards be based on unbiased and realistic performance evaluation results. A realistic assessment of reward fallouts both present and past give credence to the fact that climate of impunity has gained in-road into reward practices in some nation's universities. In certain quarters, political gimmicking, witch-hurting, backsliding, and racketeering, have infiltrated into the university appraisal corridor and are now the benchmark for determining potential beneficiaries of organization's reward package. It is a reflective of dissecting opinions that seniority and meritorious service should guide reward decision. Divergent views that reflect popular opinions have however stressed contingency and performance as deciding criteria.

While the above forethought is plausible in affirming organizational commitment to long serving staff, there are dangers in emphasizing length of service as chief criterion. In ambiguous and amorphous situations, evidence is glared, that many have outlived their mandatory year of 
active service through connivance with unscrupulous elements in the system to sabotage the effort of management. Individuals have recklessly gained undue access to university archives and data base to commit ethical fraud of age and personal data manipulation to the discredit of the university hard-earned reputation on one hand and to the displeasure of integrity keepers on the other hand. It is disheartening when employees perceive the university reward practices and procedures as they affect staff upgrade, promotion, termination, and reinstatement being selectively biased against certain individuals. Facts have emerged that individuals who experience unfair reward practices in the organization felt victimized and betrayed leading to output reduction, distrust, shabby work attitude, or outright disengagement from service. Individual often compares and rationalizes the rate of his pay per unit contribution with those of others within or outside the organization. A perception of inequity or lopsidedness in pay administration will further demoralize and kill their sense of value and personal worthiness. To leverage their potential bearing on the group and resuscitating organizational image, rewards must be built on the culture of sound ethics and abiding leadership practice obsessed with integrity.

\section{Servant Leadership and Staff Job Commitment}

The result for model $2\left(\beta=.53, p=.001, \mathrm{R}^{2}\right.$ value $=.27$, F-ratio $\left.=155.70\right)$ has affirmed strong linkage between servant leadership and job commitment of university staff. Result agrees with the findings of (Schwarz, Newman, Cooper, \& Eva, 2016). Motivated by the leader's exemplary disposition to be supportive, transparent and deliver on promises made, staffs are impelled to develop faith and confidence in their employers which often translate to staff's commitment to university goals and mission just as Saleem (Zhang, Gopinath, \& Adeel, 2020).

Analysis of respondents' pattern reveals that servant leaders possess amiable traits that others are envious of; or may even polarize as overbearing or retrogressive. Their meekness, patience, empathy, and exemplary dispositions make servant leaders earn the sympathy and trust of subordinates in conformity with the research of (Miao, Newman, Schwarz, \& Xu, 2014). As evident from sampled respondents, moral leaders prove their worth by not being belligerent or becoming puffed up but assuming a slave-like identity.

The evolving culture according staff sampled idolizes and immortalizes influential members of the societies who have little or no regard for moral discipline, resulting in tragic consequences. This finding concurs with (Chandler, 2005). The unbridled craving for self-exultation and having undue advantage over others has further demeaned a case for servant leadership. Further result has substantiated exerting influence of institutional environment in shaping leadership behavior and personality. Result has strengthened the findings of Hegarty and Moccia (2018).

The implications of the above are multi-manifold namely that: prevailing leadership architecture and ethical climate, the regulating institutions and legal frameworks and the societal definition of appropriate and orderly behavior will have strong bearing on leadership demeanor; that leadership effectiveness require that leaders empower others by providing enabling resources and facilities to bolster performance even in the most dire circumstances; that when staffs perceive their roles as one of mutually and inspiringly reinforcing, they are impelled to accept ambitiously demanding and exciting job tasks that are value-laden.

Divorcing from existing practices where leaders perceived their roles as one of domineering and self-assuming, the study stresses simplicity, self-sacrificing, self-discipline, and long-suffering as essential credentials to enhancing leadership effectiveness.

\section{Ethical Leadership, Trust, and Confidence}


Judging from the result of model 3 (as per Table 7) it can be deciphered why Nigerian University leadership should uphold high sense of morality and strong ethics in handling staff-related issues. A virile leadership anchored on core values and group norms is found to have positive bearing on staff motivation, their sense of value and confidence in management just as (Xu, Loi, \& Ngo, 2016) have concurred. Conversely staff's faith in management, its policies and programmes and job satisfaction will shrink in a work setting marred by flagrant ethical breaches where morality has descended so low.

A support of this finding was found in the study of Malik, Awais, Timsal, and Qureshi (2016) and Abun, Racoma, and Racsa (2017) but differs in structural and geographical contexts. Ethical aberration such as sexual abuse apart from denigrating the image of the university was found to lead to betrayal and eroding of public confidence. Respondents' opinions have also uncovered desires for self-dignity, job security and autonomy as work-place practices that give succor to the employees and that when a climate of impunity and filthy practices fester in the organisation, employee's right to self-determination and free-will be severely jettisoned. On the other hand, an organisational culture that accord employees' self-dignity and fair play can unleash their discretionary and innovative behaviors. This argument agrees with the work of (Yidon \& Xinxin, 2013). To preserve their image and sustain staff confidence the Management of Nigerian Universities must possess impeccable leadership credentials that are value laden. Studies have foreclosed that victims of sexual harassment felt degraded and alienated, develop self-guilt, and become demoralized (Merkin \& Shah, 2014).

Except in limited instances, the author wishes to reinstate that the cases of overt sexual harassment have not been well-established in Nigerian Universities. However, as part of proactive measures to curb the excesses of the obnoxious syndrome in nation's universities, the author posits a binding culture built on strong ethical structure perceived to be fair to all. Lopsidedness in promotion exercises influenced by the whims of University management for ulterior ends would destroy the cohesiveness of the group much so as it does to university image. The evolving practices in state universities have been for the staff appraisal and promotion processes to be selectively biased thus giving way for feeling of unworthiness and disillusionment among staff victims of management's unfair labour acts.

The university institution as a citadel of learning and pinnacle of knowledge transfer should not condescend so low as to mortgage the course of procedural justice for shabby conduct bordering on promotion, termination or appointment of university staff. Eclectic studies carried out in related areas are predominantly reflective of ethical dimension of moral leadership in other parastatals not in the Nigerian university domains.

By means of the study, the author intends to fill this void by demonstrating how integrative approach to ethical-related issues in nation's universities can be adapted to job performance of both academic and non-academic staffs. To preserve their corporate characters and self-identities, the author admonished the management and stakeholders of tertiary institutions not to let down their gowns on university core values.

\section{Inspirational Leadership and Job Retention}

The fourth regression model result (Table 8 ) where $\beta=.67$, F-statistic $=251.72$, and $p=.001$ ) revealed significant alignment between inspirational leadership and job retention. The Adjusted $\mathrm{R}^{2}$ value of .45 has suggested about $45 \%$ systematic variations in the level of job retention among staff of University. 
Instructive to relate that quite skeletal works have been ventured to link some dimensions of moral leadership to employees' retention level (Tain, Iqba, \& Khan, 2020), none of the studies has linked inspirational leadership to Job performance of university academic and non-academic staff, the void which this study has attempted to fill.

Moral leaders with inspirational gems are not only supportive but are willing to render practical helps to the disorderly and the weak in dire circumstances thus resulting in increased level of motivation and high morale boost among individuals. Regression result aptly confirmed this assertion which also in tandem with (Vallina, Simone, \& Guerrero, 2020) that found that inspirational leadership positively impacts on followers' characteristics and happiness at work.

It is a discerning of popular opinions that unambiguous articulation and clarification of group goals and expectations by university leadership would trigger performance and commitment to shared values, missions, and visions. A leader's obsession to coach, mentor and counsel subordinates, study has found, would enhance employees' self-efficacy and their citizenship behaviour. Tactful use of both intrinsic and extrinsic rewards were also found to be critical in attracting and developing employable skills as well as influencing staff's decision to stay longer in the university.

Most staff sampled also averred that they would oblige a boss who listens and admonishes with passion and keen interest. It is also expedient to realize that prior studies in moral leadership have failed to add inspirational leadership as one of the building blocks. Consequently, the author adapts inspirational leadership as an addendum to existing constructs of moral leadership to make for an all-round discourse of the subject as it affects university staff.

\section{Authentic Leadership, Staff Motivation and Sense of Belonging}

The regression result for Model 5 (see Table 9) was one of overall weak relationship thus giving credence to the argument that authentic leadership does not necessarily increase staff motivation and their sense of belonging except in extenuating circumstances. However, the result differs substantially with the findings of Hannah, Avolio, and Walumba (2011) and Hidayat (2016) but partially with that of Ribeiro, Gomes, and Kurian (2018). The overall score card for an authentic leader when measured along overall leadership scale is the one that will lead to sub-optimal performance as opposed to super-optimal performance. Due to their ingrained syndrome of doggedness and popularly held notion of conformity to standard to procedures and rules, authentic leaders are unlikely to earn subordinates' confidence short of motivating them to improve their job behaviors and performance. That employee feels trusted and engaged is one side of the coin (Danshang \& Chia-Shun, 2013) but combing these factors to drive performance towards a positive direction is on the other side of the coin. The study has contributed to extant literature by relying on intertwine of mediations to drive the train of moral leadership to staff job performance.

\section{Moral Leadership, Shared Values, Employee Engagement and Staff Job Performance}

The study has found cumulative meditating effects of shared values and employee engagement in linking moral leadership to job performance of staff of university (see Figure 3 and appendix 1). The simultaneous alignment of the mediations (in the order of shared values and then employee engagement) is inferred by the belief that staff having perceived themselves as strategic partners in aligning their values, interests and beliefs with those of the organization and colleagues and vice versa, are well-motivated to sustain their self-efficacy and building trust and commitment to missions and group purpose (Davenport \& Roberts, 2002; Malinen, Wright, \& Cammock, 2013; 
Tims, Bakker, \& Xanthopoulou, 2020). The university culture must espouse shared values, strongly anchored on strong moral edifice translated into policies, missions, goals and visions.

There is deficit or lack of empirical works that linked moral leadership with job performance of the university staff with the moderating effect of shared values and employee engagement. The shared values of organisation which the employees must recognize as both mutually reinforcing and revolving around strong ethical culture will not only increase staff' sense of worthiness and self-identity but will spur them to super-optimal performance.

\section{Extant Contributions, Originality/Value}

The study has laid bare, the importance of shared-meaning, shared-values, and shared-vision, augmented with organizational sense of identity, in aligning expanded constructs of moral leadership with job performance of staff of Nigerian Universities. The study is supposedly the first in sub-Sahara Africa and diaspora to examine simultaneous moderating effect of shared values and employee engagement in the university's moral leadership-staff job performance link. Again, by developing integrated and robust constructs of moral leadership into a coherent building block, the study has established how expanded dimensions of moral leadership can be adapted to job performance measures of university staff for optimum performance.

Withal, by using synthesis of analytical tools (regression model and structural equation modelling, etc.) to explain how modified constructs of moral leadership mediated by share values and employee engagement could lead to job performance of academic and non-academic staff of Nigerian universities, the study has demonstrated the necessity to build into coherent and inclusive framework the leadership architectures and moral fabrics of Nigerian universities for excelling services and robust management-staff relationship.

Finally, by adapting and upgrading Lemoine et al.'s (2018) concept of moral leadership to five constructs, the study has provided a coherent and all-round framework that shape management's sense of value and ethical decorum in the university leadership architecture.

\section{Conclusion}

Nigeria as a sovereign nation is not in deficit of pool of talented and energetic individuals with diverse leadership credentials. Nonetheless, the knot of governing and nurturing university system to unenviable height is quite beyond mere possession of latent administrative, technical, or intellectual skills to manage relationships and resources. The unceasing pressures to mortgage core values for personal aggrandizement and compelling demands by stakeholders for moral decency and corrupt-free society has laid bare the vital question of which side of the issue to toe - to be moral or amoral. University management must sustain the right pedigree and leadership acumen found on unbroken moral edifice to navigate through multi-faceted challenges faced by the institutions. Resting on stakeholder and social exchange theories and using regression model and structural equation modelling as analytical tools, the study has sought to find out if share values and employee engagement mediate between the constructs of moral leadership and job performance measures of university staff. The sample respondents which included both teaching and nonteaching staff are the vulnerable and often are the victims of University's unfair labour practices. From the foregoing it is evident that shared values and employee engagement moderate the effect of moral leadership on job performance. However, one dimension of moral leadership (authentic leadership) was found to have negative influence on university staff in terms of motivation. It is germane that management builds commitment to and emphasis moral leadership constructs of value 
reward, servant, ethical, and inspirational but to deemphasize the authentic leadership except in extenuating circumstances.

\section{References}

Abun, D., Racoma, A., \& Racsa, L. R. (2017). Moral leadership of middle-lower level managers and employee's job satisfaction of Divine Word Colleges in Region 1, Philippines as perceived by the employees. IJRDO-Journal of Business Management, 3(9), 257-288. Retrieved from https://hal.archives-ouvertes.fr/hal-02334352/

Ajmal, A., Bashir, M., Abrar, A., Khan, M. M., \& Saqib, S. (2015). The effects of intrinsic and extrinsic rewards on employee attitudes: Mediating role of perceived organizational support. Journal of Service Science and Management, 8(4), 461-470. https://doi.org/10.4236/jssm.2015.84047

Al Darmaki, S. J., Omar, S., \& Wan Ismail, W. (2019). Driving innovation: Reviewing the role of rewards. Journal of Human Resource and Sustainability Studies, 7(3), 406-415. https://doi.org/10.4236/jhrss.2019.73027

Allen, G. H. (2006). Failures of total quality management: products of leadership and organisational culture. Community College Journal of Research and Practice, 18(4), 381-390. https://doi.org/10.1080/1066892940180406

Asiff, M., Qing, M., Hwang, J., \& Shi, H. (2019). Ethical leadership, affective commitment, work engagement, and creativity: Testing a multiple mediation approach. Sustainability, 11(16), 1-16. https://doi.org/10.3390/su11164489

Bao, Y., \& Li, C. (2019). From moral leadership to positive work behaviors: the mediating roles of value congruence and leadermember exchange. Frontiers of Business Research in China, 13(6). https://doi.org/10.1186/s11782-019-0052-3

Bao, Y., Lin, L., \& Liu, D. (2017). Leveraging the employee voice: A multi-level social learning perspective of ethical leadership. The International Journal of Human Resource Management, $10(12), \quad 1869-1901$. https://doi.org/10.1080/09585192.2017.1308414

Baron, M. W., Pettit, P., \& Slote, M. (1997). Three methods of ethics: A debate. Hoboken, NJ: Willey-Blackwell.

Bedi, A., Alpaslan, C. M., \& Green, S. (2015). A meta-analytic review of ethical leadership outcomes and moderators. Journal of Business Ethics, 139(3), 1-20. https://doi.org/10.1007/s10551-015-2625-1

Biza, T. A., \& Mama Irbo, M. (2020). The impact of leadership styles on employee commitment in Madda Walabu university. African Journal of Business Management, 14(9), 291-300. https://doi.org/10.5897/AJBM2018.8603

Carucci, R. (2016). Why ethical people make unethical choices. Harvard Business Review. Retrieved from https://hbr.org/2016/12/why-ethical-people-make-unethical-choices

Casimir, Izueke, \& Nzekwe, (2014). Public sector and corruption in Nigeria: An ethical and institutional framework of analysis. Open Journal of Philosophy, 4(3), 216-224. https://doi.org/10.4236/ojpp.2014.43029

Chandler, R. C. (2005). Avoiding unethical misconduct disasters. Graziadio Business Review, 8(3). Retrieved from https://gbr.pepperdine.edu/2010/08/avoiding-ethical-misconduct-disasters/

Changsuk, K., Jianhong, M., Roman, B., Mark, H., H., \& Mingu, K. (2017). Ethical leadership: An integrative review and future research agenda. Ethics and Behavior, 28(2), 104-132. https://doi.org/10.1080/10508422.2017.1318069

Crossman, A. (2020). Understanding social exchange theory. Retrieved from https://thoughtco.com/social-exchange-theory3026634

Dan-shang, W., \& Chia-Shun, H. (2013). The effect of authentic leadership on employee trust, and employee engagement, social behavior and personality. An International Journal, 41(4), 613-624. https://doi.org/10.2224/sbp.2013.41.4.613

Davenport, T. O., \& Roberts, D. R., (2002). Job engagement: Why it's important and how to improve it. Employment Relation, 29(3), 21-29. https://doi.org/10.1002/ert.10048

De Cremer, D., \& Vandekerckhove, W. (2017). Managing unethical behavior in organizations: The need for a behavioral business ethics approach. Journal of Management and Organization, 23(3), 437-455. https://doi.org/10.1017/jmo.2016.4

Donalson, T., \& Peterson, L. E. (1995). The stakeholder theory of the corporation: Concepts, evidences, and implications. Academy of Management Review, 20(1), 65-91. Retrieved from http://www.jstor.org/stable/258887

Engelbrecht, A. S., Gardielle, H., \& Mahembe, M. (2017). Integrity, ethical leadership, trust and work engagement. Leadership and Organizational Development Journal, 38(3), 368-379. https://doi.org/10.1108/LODJ-11-2015-0237

Freeman, R. E. (1984). Strategic management: A stakeholder approach. New York: Pitman Publishers. Retrieved from https://ssrn.com/abstract=263511

Fudge, R. S., \& Schlacter, J. L. (1999). Motivating employees to act ethically: An expectancy theory approach. Journal of Business Ethics, 8, 295-304. https://doi.org/10.1023/A:1005801022353 
Gino, F. (2015). Understanding ordinary unethical behaviors: why people who value morality act immorally. Current Opinion in Behavioral Sciences, 3(1), 107-111. https://doi.org/10.1016/j.cobeha.2015.03.001

Hidayat, S. (2016). Authentic Leadership is source of intrinsic motivation in work engagement with moderating role of overall trust, cognitive and affective trust. Journal of multi-disciplinary Engineering Science and Technology, 3(3), 4236-4242. Retrieved from https://iiste.org/Journals/index.php/JRDM/article/view/29348

Hannah, S., Avolio, B. J., \& Walumba, F. O. (2011). Relationship between authentic leadership, moral courage, and ethical and pro-social behaviors. Business Ethics Quarterly, 21(4), 555-578. https://doi.org/10.5840/beq201121436

Hegarty, N., \& Moccia, S. (2018). Components of ethical leadership and their importance in sustaining organizations over the long-term. The Journal of Value-based Leadership, 11(1). http://dx.doi.org/10.22543/0733.111.1199

Homans, G. (1961). Social behavior: its elementary forms. New York: Harcourt Brace Jovanovich, 40(2), $180-181$. https://doi.org/10.2307/2574301

Hoseah, E. G. (2014). Corruption as a global hindrance to promoting ethics, integrity and sustainable development in Tazania: the role of anti-corruption agency. Journal of Global Ethics, 10(3), 384-392. https://doi.org/10.1080/17449626.2014.973995

Hoyt, C. L., Price, T. L., \& Poatsy, L. (2013). The social role theory of unethical leadership. The Leadership Quarterly, 24(5), 712-723. https://doi.org/10.1016/j.leaqua.2013.07.001

Kempe, R. H. (1999). Corruption in Africa: A crisis in ethical leadership. Public Integrity, 1(3), 289-308. Retrieved from https://www.researchgate.net/publication/273944947_Corruption_in_Africa_A_Crisis_in_Ethical_Leadership

Kendra, C. (2020). Social comparison theory in psychology. Retrieved from https://www.verywellmind.com/what-is-the-socialcomparison-process-2795872

Kraatz, M. S., Flores, R., \& Chandler, D. (2020). The values of values for institutional analysis. Academy of Management Annals, 14(2). https://doi.org/10.5465/annals.2018.0074

Kurland, N. B. (1995). The unexplored territory linking rewards and ethical behavior: A review and a diagnostic model. Business and Society Journal, Sage Pub, 34(1), 34-50. https://doi.org/10.1177/000765039503400103

Lambert, E. G., Keena, L. D., Leone, M., May, D., \& Haynes (2020). The effects of distributive and procedural justice on job satisfaction and organizational commitment of correctional staff. The Social Science Journal, 57(4), 405416.https://doi.org/10.1016/j.soscij.2019.02.002

Lemoine, G. J., Hartnell, C. A., \& Leroy, H. (2018). Taking stock of moral approaches to leadership: An integrative review of ethical, authentic, and servant leadership. Academy of Management Annals, 13(1). https://doi.org/10.5465/annals.2016.0121

Li, F., Chen, T., \& Lai, X., (2017). How does reward for creativity program benefit or frustrate employee creative performance? The perspective of transactional model of stress and coping. Organisation and Group Management, Sage Journals, 43(1), 138175. https://doi.org/10.1177/1059601116688612

Liu, H. (2010). When leaders fall: A typology of Failures and framing strategies. Management Communication Quarterly, 24(2), 232-259. http://mcq.sagepub.com/content/24/2/232

Mackey, J. D., Frieder, R. E., Brees, J. R., \& Martinko, M. J. (2017). Abuse supervision: A meta-analysis and empirical review. Journal of Management, 43(6), 1940-1965. https://doi.org/10.1177/0149206315573997

Malik, M. S., Awais, M., Timsal, A., \& Qureshi, U., H. (2016). Impact of ethical leadership on employees' performance: Moderating role of organizational values. International Review of Management and Marketing, 6(3), 590-595. https://www.researchgate.net/publication/305488961

Malinen, S., Wright, S., \& Cammock, P. (2013). What drives organizational engagement? A case study on trust. Evidenced-based HRM, a Global Form for Empirical Scholarship, 1(1), 96-108. https://doi.org/10.1108/20493981311318638

Merkin, R., \& Shah, M. K. (2014). The impact of sexual abuse on job satisfaction, turnover intentions, and absenteeism: Findings from Parkistan compared to the United States. Springerplus, 3(215). https://doi.org/10.1186/2193-1801-3-213

Miao, Q., Newman, A., Schwarz, G., \& Xu, L. (2014). Servant leadership, trust, and the organizational commitment of public sector employees. Journal of Public Administration, 92(3). https://doi.org/10.1111/padm.1291.

Mihelic, K. K., Lipicnik, B., \& Tekavecic, M., (2010). Ethical leadership. International Journal of Management and Information Systems, 14(5), 1-12. https://doi.org/10.19030/ijmis.v14i5.11

Mitroff, I. (1983). Stakeholders of the organizational mind. San Francisco: Jessey-Bass Publishers, 178. https://doi.org/10.1002/hrm.3930230409

Ribeiro, N., Gomes, D., \& Kurian, S. (2018). Authentic leadership and performance: The mediating role of employees' affective commitment. Social Responsibility Journal, 14(1), 213-225. https://doi.org/10.1108/SRJ-06-2017-0111

Russell, R. F. (2001). The role of values in servant leadership. Leadership and Organisation Development Journal, 22(2), 76-84. https://doi.org/10.1108/01437730110382631

Salah, M. R. A. (2016). The influence of reward on employees' performance. British Journal of Economics, Management and Trade, 13(4), 1-25. https://doi.org/10.9734/BJEMT/2016/25822 
Saleem, F., Zhang, Y. Z., Gopinath, C., \& Adeel, A. (2020). Impact of servant leadership on performance: The mediating role of affective and cognitive trust. Sage Journals: Leadership, Business Law and Business Ethics, 10(1). https://doi.org/10.1177/2158244019900562

Schwarz, Q., Newman, A., Cooper, B., \& Eva, N. (2016). Servant leadership and follower job performance: The mediating effect of public service motivation. Public Administration, 94(4). https://doi.org/10.1111/padm.12266

Sendjaya, S. (2005). Morality and leadership: Examining the ethics of transformational leadership. Journal of Academic Ethics, 3(1), 75-86. https://doi.org/10.1007/s10805-005-0868-7

Shakeel, F., Kruyen, P. M., \& Thiel, S. V. (2019). Ethical Leadership as a process: A conceptual proposition. Journal of Public Integrity, 21(6), 613-624. https://doi.org/10.1080/10999922.2019.1606544

Solinger, O. N., Jansen, P., \& Cornelissen, J. P. (2020). The emergence of moral leadership. Academy of Management Review, 45(3), 504-527. https://doi.org/10.5465/amr.2016.0263

Spears, L. (1996). Reflections on Robert K. Greenleaf and servant-leadership. Leadership and Organisational Development Journal, 17(7), 33-35. https://doi.org/10.1108/01437739610148367

Tain, H., IqbaI, S., \& Khan, S. (2020). The impact of transformational leadership on employee retention: Mediating and moderation through organisational citizenship behavior and communication. Organisation Psychology, 11, 314. https://doi.org/10.3389/fpsyg.2020.00314

Tims, M., Bakker, A. B., \& Xanthopoulou, D. (2020). Do transformational leaders enhance their followers' daily work engagement? The Leadership Quarterly, 22(1), 121-131. https://doi.org/10.1016/j.leaqua.2010.12.011

Vallina, A. S., Simone, C., \& Guerrero, R. F. (2020). The human side of leadership: Inspirational leadership effects on followers' characteristics and happiness at work. Journal of Business Research, 107(C), 162-171. https://doi.org/10.1016/j.jbusres.2018.10.044

Wang, Y., \& Li, H. (2019). Moral leadership and unethical pro-organisational behavior: A moderated mediation model. Frontiers in Psychology: Organisational Psychology, 10: 2640. https://doi.org/10.3389/fpsyg.2019.02640

Xu, A., Loi, R., \& Ngo, H. (2016). Ethical leadership behavior and employee justice perceptions: The mediating role of trust in organization. Journal of Business Ethics, 134, 493-504. https://doi.org/10.1007/s10551-014-2457-4

Yidon, T., \& Xinxin, L. (2013). How ethical leadership influence employee's innovative work behavior: A perspective of intrinsic motivation. Journal of Business Ethics, 116(2), 441-455. http://dx.doi.org/10.1007/s10551-012-1509-x

Yuki, G. A. (2010). Leadership in organizations (7 $7^{\text {th }}$ ed.). Upper Saddle River, NY: Prentice Hall. 


\section{Appendix 1}

\begin{tabular}{|c|c|c|c|c|c|c|}
\hline Structural equation model & $\begin{array}{l}\text { ion model } 1 \\
\begin{aligned} & =\mathrm{m} 1 \\
& =-273\end{aligned}\end{array}$ & 9237 & & \multicolumn{2}{|c|}{ Number of obs } & 368 \\
\hline (1) [v]ship & ILSHIP $=1$ & & & & & \\
\hline & & OIM & & & & \\
\hline & Coef. & std. Err. & $z$ & $P>|z|$ & [95\% Conf. & Interval] \\
\hline \multicolumn{7}{|l|}{ structural } \\
\hline eengsv $<-$ & & & & & & \\
\hline MLSHIP & -.0174622 & .0664238 & -0.26 & 6.793 & -.1475994 & .1127861 \\
\hline _cons & 4.31 & .6346212 & 126.69 & 6.698 & 4.24332 & 4.37668 \\
\hline sjperf <- & & & & & & \\
\hline eengsv & .6822861 & .0428236 & 15.93 & 6.000 & .5983533 & .7662188 \\
\hline MLSHIP & .0252775 & .0490215 & 0.52 & 6.696 & - . 6790929 & .1213579 \\
\hline _cons & 1.349347 & .1862876 & 7.24 & 6. 609 & .9842302 & 1.714464 \\
\hline \multicolumn{7}{|l|}{ Measurement } \\
\hline viship $<-$ & \multirow{2}{*}{\multicolumn{3}{|c|}{1 (constrained) }} & & & \\
\hline MLSHIP & & & & & & \\
\hline _cons & 3.58 & .6743178 & 48.17 & 6. 808 & 3.43434 & 3.72566 \\
\hline \multicolumn{7}{|l|}{ slship <- } \\
\hline MLSHIP & 1.777664 & .3326994 & 5.35 & 6.ees & 1.126761 & 2.428566 \\
\hline - cons & 3.72 & .0678625 & 54.82 & 6.009 & 3.586992 & 3.853e98 \\
\hline \multicolumn{7}{|l|}{ elship $<-$} \\
\hline MLSHIP & 1.262945 & .2641274 & 6.19 & 0.609 & .8628623 & 1. 663027 \\
\hline -cons & 3.39 & .6676975 & 58.14 & 6. 898 & 3.257492 & 3.522508 \\
\hline \multicolumn{7}{|l|}{ ilship <- } \\
\hline MLSHIP & .5995465 & .1525952 & 3.93 & e. 689 & .3994655 & .8986275 \\
\hline - cons & 3.57 & .073146 & 48.81 & 6.609 & 3.426637 & 3.713363 \\
\hline \multicolumn{7}{|l|}{ alship $<-$} \\
\hline MLSHIP & .3139492 & .1269329 & 2.62 & 0.009 & .078689 & .5492093 \\
\hline -cons & 3.27 & .0597337 & 54.74 & 6.600 & 3.152924 & 3.387076 \\
\hline $\operatorname{var}(e \cdot v 1 s h i p)$ & 1.3255 & 1233748 & & & 1,184464 & 1.596771 \\
\hline $\operatorname{var}(e . s 1$ ship) & .3342267 & .1366275 & & & .1499917 & .7447312 \\
\hline $\operatorname{var}(e \cdot e l s h i p)$ & .8425772 & .088167 & & & .6863415 & 1.034378 \\
\hline $\operatorname{var}(e . i l s h i p)$ & 1.485962 & .1255497 & & & 1. 259199 & 1.753562 \\
\hline $\operatorname{var}(e \cdot a l s h i p)$ & 1.037765 & .0855338 & & & .8829624 & 1. 219709 \\
\hline $\operatorname{var}(e \cdot$ eengsv) & .347133 & .0283454 & & & .2957947 & .4973815 \\
\hline $\operatorname{var}(e \cdot s j p e r f)$ & .1969118 & .0155922 & & & .1626721 & .2246538 \\
\hline $\operatorname{var}(M L S H I P) \mid$ & .3314391 & .1694887 & & & .1829485 & .6094524 \\
\hline
\end{tabular}




\section{Appendix 2}

Presentation of data and respondents' response pattern

\begin{tabular}{|c|c|c|c|c|c|c|c|c|c|c|c|}
\hline \multicolumn{12}{|c|}{ Value reward leadership } \\
\hline & Questionnaire Items & \multicolumn{2}{|c|}{$\mathrm{U}(1)$} & \multicolumn{2}{|c|}{$\mathrm{SD}(2)$} & \multicolumn{2}{|c|}{$\mathrm{D}(3)$} & \multicolumn{2}{|c|}{$\mathrm{A}(4)$} & \multicolumn{2}{|c|}{ SA (5) } \\
\hline & & No & $\%$ & No & $\%$ & No & $\%$ & No & $\%$ & No & $\%$ \\
\hline 1 & $\begin{array}{l}\text { Rewards fill a need if they are not sentimentally } \\
\text { determined. }\end{array}$ & - & - & 29 & 9.7 & 39 & 13 & 144 & 48 & 88 & 29.3 \\
\hline 2 & $\begin{array}{l}\text { Rewards should be based on accurate and realistic } \\
\text { performance appraisal outcomes. }\end{array}$ & 26 & 8.7 & 48 & 6 & 41 & 13.6 & 39 & 13 & 146 & 48.7 \\
\hline 3 & $\begin{array}{l}\text { Organization's reward decision should be reflective of } \\
\text { staff length of stay and meritorious services. }\end{array}$ & 10 & 3.3 & 27 & 9 & 19 & 6.3 & 155 & 51.7 & 89 & 29.7 \\
\hline 4 & $\begin{array}{l}\text { The university reward practice as it relates to appointment } \\
\text { and staff upgrade should be fair. }\end{array}$ & 20 & 6.7 & 20 & 6.7 & 49 & 16.3 & 117 & 39 & 94 & 31.3 \\
\hline 5 & $\begin{array}{l}\text { The reward policies and procedures affecting termination } \\
\text { and reinstatement should be perceived by staff as being } \\
\text { fair. }\end{array}$ & - & - & 9 & 3 & 29 & 9.7 & 174 & 58 & 88 & 29.3 \\
\hline 6 & $\begin{array}{l}\text { Reward decisions in the university should make } \\
\text { allowance for effort and contribution. }\end{array}$ & 6 & 2 & 18 & 6 & 41 & 13.7 & 89 & 29.7 & 146 & 48.7 \\
\hline 7 & $\begin{array}{l}\text { Management should opt for equity-based reward practice } \\
\text { for its staff. }\end{array}$ & 10 & 3.3 & 21 & 7 & 25 & 8.3 & 105 & 35 & 139 & 46.3 \\
\hline
\end{tabular}

\begin{tabular}{|c|c|c|c|c|c|c|c|c|c|c|c|}
\hline \multicolumn{12}{|c|}{ Servant leadership } \\
\hline & Questionnaire Items & \multicolumn{2}{|c|}{$\mathbf{U}(\mathbf{1})$} & \multicolumn{2}{|c|}{ SD (2) } & \multicolumn{2}{|c|}{ D (3) } & \multicolumn{2}{|c|}{$\mathbf{A ~ ( 4 )}$} & \multicolumn{2}{|c|}{ SA (5) } \\
\hline & & No & $\%$ & No & $\%$ & No & $\%$ & No & $\%$ & No & $\%$ \\
\hline 1 & Leaders should recognize their strengths and limitations. & - & - & 29 & 9.7 & 39 & 13 & 88 & 29.3 & 144 & 48 \\
\hline 2 & $\begin{array}{l}\text { University officials should lead by examples in imparting } \\
\text { moral values on others. }\end{array}$ & 10 & 3.3 & 27 & 9 & 19 & 6.3 & 155 & 51.7 & 89 & 29.7 \\
\hline 3 & $\begin{array}{l}\text { Understanding and listening leader garner more } \\
\text { momentum than the unreceptive and un-caring one. }\end{array}$ & - & - & 28 & 9.3 & 40 & 13.4 & 88 & 29.3 & 144 & 48 \\
\hline 4 & $\begin{array}{l}\text { Empathetic leader that cares for and reflects the feelings } \\
\text { and concerns of the subordinates gain acceptance and } \\
\text { mandate of the group. }\end{array}$ & 25 & 8.3 & 49 & $\begin{array}{l}16 . \\
3\end{array}$ & 41 & 13.6 & 39 & 13 & 146 & 48.7 \\
\hline 5 & $\begin{array}{l}\text { Leaders should live above-board to inculcate moral } \\
\text { discipline on others. }\end{array}$ & 27 & 9 & 10 & 3.3 & 10 & 3.3 & 164 & 54.7 & 89 & 29.7 \\
\hline
\end{tabular}

\begin{tabular}{|c|c|c|c|c|c|c|c|c|c|c|c|}
\hline \multicolumn{12}{|c|}{ Ethical leadership } \\
\hline & Questionnaire Items & \multicolumn{2}{|c|}{$\mathbf{U}(\mathbf{1})$} & \multicolumn{2}{|c|}{ SD (2) } & \multicolumn{2}{|c|}{ D (3) } & \multicolumn{2}{|c|}{ A (4) } & \multicolumn{2}{|c|}{ SA (5) } \\
\hline & & No & $\%$ & No & $\%$ & No & $\%$ & No & $\%$ & No & $\%$ \\
\hline 1 & $\begin{array}{l}\text { University leadership should uphold high sense of } \\
\text { morality and sound ethics in administrative matters. }\end{array}$ & 20 & 6.7 & 20 & 6.7 & 49 & 16.3 & 117 & 39 & 94 & 31.3 \\
\hline 2 & $\begin{array}{l}\text { A climate of impunity that promotes perpetual sexual } \\
\text { abuse would negate the good image of the institution. }\end{array}$ & 10 & 3.3 & 27 & 9 & 18 & 6 & 156 & 52 & 89 & 29.7 \\
\hline 3 & $\begin{array}{l}\text { A culture of impunity that violates employees' free-will } \\
\text { and right to self-determination will breed mistrust and } \\
\text { negative motivation. }\end{array}$ & - & - & 29 & 9.7 & 39 & 13 & 88 & 29.3 & 144 & 48 \\
\hline 4 & $\begin{array}{l}\text { In an organisation where key management decisions and } \\
\text { programmes are jettisoned for ulterior ends will lead to } \\
\text { betrayal of confidence and trust. }\end{array}$ & 26 & 8.7 & 39 & 13 & 39 & 13 & 50 & 16.7 & 146 & 48.7 \\
\hline 5 & $\begin{array}{l}\text { A lopsided promotion exercises influenced by the whims } \\
\text { of the boss for ulterior purpose will destroy group } \\
\text { cohesiveness }\end{array}$ & 10 & 3.3 & 27 & 9 & 19 & 6.3 & 155 & 51.7 & 89 & 29.7 \\
\hline 6 & $\begin{array}{l}\text { The university administration must not sacrifice the } \\
\text { course of justice for shabby conduct }\end{array}$ & 20 & 6.7 & 12 & 4 & 39 & 13 & 117 & 39 & 111 & 37 \\
\hline
\end{tabular}

\begin{tabular}{|c|c|c|c|c|c|c|c|c|c|c|c|}
\hline \multicolumn{12}{|c|}{ Inspirational leadership } \\
\hline & Questionnaire Items & \multicolumn{2}{|c|}{ U (1) } & \multicolumn{2}{|c|}{ SD (2) } & \multicolumn{2}{|c|}{ D (3) } & \multicolumn{2}{|c|}{ A (4) } & \multicolumn{2}{|c|}{ SA (5) } \\
\hline & & No & $\%$ & No & $\%$ & No & $\%$ & No & $\%$ & No & $\%$ \\
\hline 1 & $\begin{array}{l}\text { Moral leaders must be supportive and be willing to render } \\
\text { practical help to disorderly and the weak in dire } \\
\text { circumstances. }\end{array}$ & - & - & 28 & 9.3 & 40 & 13.4 & 88 & 29.3 & 144 & 48 \\
\hline 2 & $\begin{array}{l}\text { University leadership must be articulate enough to clarify } \\
\text { individual and group expectations. }\end{array}$ & - & - & 9 & 3 & 29 & 9.7 & 174 & 58 & 88 & 29.3 \\
\hline 3 & $\begin{array}{l}\text { A good leader must develop the capacity to coach and } \\
\text { mentors' others. }\end{array}$ & - & - & 29 & 9.7 & 39 & 13 & 144 & 48 & 88 & 29.3 \\
\hline
\end{tabular}




\begin{tabular}{|c|l|l|l|l|l|l|l|l|l|l|l|}
\hline 4 & $\begin{array}{l}\text { Inspiration leaders make combined use of both intrinsic } \\
\text { and extrinsic rewards to attract and retain employable } \\
\text { skills. }\end{array}$ & 26 & 8.7 & 48 & 16 & 41 & 13.6 & 39 & 13 & 146 & 48.7 \\
\hline 5 & $\begin{array}{l}\text { A moral leader with inspirational drive displays a deep } \\
\text { sense of humor and foresight to others. }\end{array}$ & 10 & 3.3 & 27 & 9 & 19 & 6.3 & 155 & 51.7 & 89 & 29.7 \\
\hline
\end{tabular}

\section{Authentic leadership}

\begin{tabular}{|c|l|l|l|l|l|l|l|l|l|l|l|}
\hline 1 & $\begin{array}{l}\text { Moral leaders are men of their words who develop } \\
\text { employee self confidence }\end{array}$ & 25 & 8.3 & 49 & $\begin{array}{l}16 . \\
3\end{array}$ & 41 & 13.6 & 39 & 13 & 146 & 48.7 \\
\hline 2 & $\begin{array}{l}\text { Moral leaders are task-oriented who lead by the power of } \\
\text { reward }\end{array}$ & 27 & 9 & 10 & 3.3 & 10 & 3.3 & 164 & 54.7 & 89 & 29.7 \\
\hline 3 & $\begin{array}{l}\text { Organisational leaders are always conscious of their } \\
\text { position }\end{array}$ & 26 & 8.7 & 48 & 16 & 41 & 13.6 & 39 & 13 & 146 & 48.7 \\
\hline 4 & $\begin{array}{l}\text { Authentic leaders are aware of their strengths and } \\
\text { weaknesses }\end{array}$ & 10 & 3.3 & 27 & 9 & 19 & 6.3 & 155 & 51.7 & 89 & 29.7 \\
\hline 5 & $\begin{array}{l}\text { Authentic leaders could a times be selfish and insensitive } \\
\text { to subordinates' plights }\end{array}$ & 20 & 6.7 & 20 & 6.7 & $\begin{array}{l}11 \\
7\end{array}$ & 39 & 49 & 16.3 & 94 & 31.3 \\
\hline
\end{tabular}

\section{Productivity}

\begin{tabular}{|c|c|c|c|c|c|c|c|c|c|c|c|}
\hline $\mathrm{s}$ & Questionnaire Items & & & & & & (3) & & & & \\
\hline 1 & $\begin{array}{l}\text { I work hard when my boss offers reward according to my } \\
\text { worth in the organization. }\end{array}$ & - & - & - & - & 29 & 12.6 & 174 & 58 & 97 & 32.3 \\
\hline 2 & $\begin{array}{l}\text { Staff become efficient when staff appraisal system is } \\
\text { perceived as being fair and based on realistic standard. }\end{array}$ & - & - & - & - & 69 & 23 & 137 & 45.7 & 94 & 31.3 \\
\hline 3 & $\begin{array}{l}\text { Staff should be promoted based on their work experience } \\
\text { and seniority }\end{array}$ & 29 & 9.7 & - & - & 39 & 13 & 144 & 48 & 88 & 29.3 \\
\hline 4 & $\begin{array}{l}\text { An effective reward system would increase the pace of } \\
\text { work }\end{array}$ & 26 & 8.7 & 48 & 16 & 41 & 13.6 & 39 & 13 & 146 & 48.7 \\
\hline 5 & $\begin{array}{l}\text { Fair reward will enhance self-confidence and } \\
\text { performance. }\end{array}$ & 10 & 3.3 & 27 & 9 & 19 & 6.3 & 155 & 51.7 & 89 & 29.7 \\
\hline 6 & Unbiased rewards will lead to greater job satisfaction. & 20 & 6.7 & 15 & 5 & 54 & 18 & 117 & 39 & 94 & 31.3 \\
\hline
\end{tabular}

\section{Job commitment}

\begin{tabular}{|c|l|l|l|l|l|l|l|l|l|l|l|}
\hline 1 & $\begin{array}{l}\text { Staff confidence and trust in management will enhance } \\
\text { with adequate supply of facilities and resources. }\end{array}$ & 29 & 9.7 & - & - & 39 & 13 & 144 & 48 & 88 & 29.3 \\
\hline 2 & $\begin{array}{l}\text { Employees accept ambitiously challenging and exciting } \\
\text { tasks that are value-laden. }\end{array}$ & - & - & - & - & 29 & 12.6 & 174 & 58 & 97 & 32.3 \\
\hline 3 & $\begin{array}{l}\text { Under proper leadership, employees would perform their } \\
\text { work voluntarily and enthusiastically. }\end{array}$ & - & - & 29 & 9.7 & 39 & 13 & 144 & 48 & 88 & 29.3 \\
\hline 4 & $\begin{array}{l}\text { Employee' self-identity will increase if his/her needs are } \\
\text { cared for. }\end{array}$ & 26 & 8.7 & 48 & 16 & 41 & 13.6 & 39 & 13 & 146 & 48.7 \\
\hline 5 & $\begin{array}{l}\text { Staff level of trust and faith in the organisation will } \\
\text { improve with an exemplary leadership in place. }\end{array}$ & 10 & 3.3 & 27 & 9 & 19 & 6.3 & 155 & 51.7 & 89 & 29.7 \\
\hline
\end{tabular}

Trust and confidence building

\begin{tabular}{|c|l|l|l|l|l|l|l|l|l|l|l|}
\hline 1 & $\begin{array}{l}\text { Employees trust and confidence in management will } \\
\text { descend low in an unethical work situation. }\end{array}$ & - & - & 29 & 9.7 & 39 & 13 & 144 & 48 & 88 & 29.3 \\
\hline 2 & $\begin{array}{l}\text { Employees felt hurt and betrayed when they are sexually } \\
\text { harassed. }\end{array}$ & 26 & 8.7 & 48 & 16 & 41 & 13.6 & 39 & 13 & 146 & 48.7 \\
\hline 3 & $\begin{array}{l}\text { Denial of staff' free-will and self-determination will breed } \\
\text { mistrust and negative motivation. }\end{array}$ & 10 & 3.3 & 27 & 9 & 19 & 6.3 & 155 & 51.7 & 89 & 29.7 \\
\hline 4 & $\begin{array}{l}\text { An unhealthy ethical climate will lead to breach of trust } \\
\text { and self-confidence. }\end{array}$ & 20 & 6.7 & 20 & 6.7 & 49 & 16.3 & 117 & 39 & 94 & 31.3 \\
\hline 5 & $\begin{array}{l}\text { Group cohesiveness will be broken with promotion } \\
\text { exercise that is perceived to be prejudiced. }\end{array}$ & - & - & 9 & 3 & 29 & 9.7 & 174 & 58 & 88 & 29.3 \\
\hline 6 & $\begin{array}{l}\text { Employees are tempted to give up good and cling to } \\
\text { dubious behavior when the course of integrity is traversed. }\end{array}$ & 6 & 2 & 18 & 6 & 41 & 13.7 & 89 & 29.7 & 146 & 48.7 \\
\hline
\end{tabular}

\section{Job retention}

\begin{tabular}{|c|l|l|l|l|l|l|l|l|l|l|l|}
\hline 1 & $\begin{array}{l}\text { Staff level of motivation and morale are high when they } \\
\text { are supported and their needs cared for promptly. }\end{array}$ & - & - & 9 & 3 & 29 & 9.7 & 174 & 58 & 88 & 29.3 \\
\hline 2 & $\begin{array}{l}\text { Employees performance often increases when } \\
\text { organisational goals and their expectations are made more } \\
\text { explicit and communicated. }\end{array}$ & 10 & 3.3 & 27 & 9 & 19 & 6.3 & 155 & 51.7 & 89 & 29.7 \\
\hline 3 & $\begin{array}{l}\text { Employees' self-efficacy and organizational identity will } \\
\text { be influenced with appropriate mentorship and training. }\end{array}$ & - & - & 28 & 9.3 & 40 & 13.4 & 88 & 29.3 & 144 & 48 \\
\hline
\end{tabular}




\begin{tabular}{|l|l|l|l|l|l|l|l|l|l|l|l|}
\hline 4 & $\begin{array}{l}\text { Employable skills and decision to stay longer in the } \\
\text { organisation are linked to the value of rewards. }\end{array}$ & 25 & 8.3 & 49 & $\begin{array}{l}16 . \\
3\end{array}$ & 41 & 13.6 & 39 & 13 & 146 & 48.7 \\
\hline 5 & $\begin{array}{l}\text { I will oblige a boss who listens and admonishes with } \\
\text { passion and keen interest. }\end{array}$ & 27 & 9 & 10 & 3.3 & 10 & 3.3 & 164 & 54.7 & 89 & 29.7 \\
\hline
\end{tabular}

Motivation and sense of belonging

\begin{tabular}{|c|l|l|l|l|l|l|l|l|l|l|l|}
\hline 1 & $\begin{array}{l}\text { I feel depressed when my boss pays little attentions to my } \\
\text { concerns. }\end{array}$ & - & - & 9 & 3 & 29 & 9.7 & 174 & 58 & 88 & $\begin{array}{l}29 . \\
3\end{array}$ \\
\hline 2 & I cannot work under a bully leader & 10 & 3.3 & 27 & 9 & 18 & 6 & 156 & 52 & 89 & $\begin{array}{l}29 . \\
7\end{array}$ \\
\hline 3 & $\begin{array}{l}\text { A leader who always imposes his ideas and wishes on } \\
\text { others will lose the trust of the group. }\end{array}$ & - & - & 29 & 9.7 & 39 & 13 & 88 & 29.3 & 144 & 48 \\
\hline 4 & $\begin{array}{l}\text { I will quit the organisation under a boss who is self- } \\
\text { centered. }\end{array}$ & 26 & 8.7 & 39 & 13 & 39 & 13 & 50 & 16.7 & 146 & $\begin{array}{l}48 . \\
7\end{array}$ \\
\hline 5 & $\begin{array}{l}\text { I will align with a superior who encourages and strengthen } \\
\text { me to meet my targets. }\end{array}$ & 10 & 3.3 & 27 & 9 & 19 & 6.3 & 155 & 51.7 & 89 & $\begin{array}{l}29 . \\
7\end{array}$ \\
\hline
\end{tabular}

\section{Employee engagement}

\begin{tabular}{|l|l|l|l|l|l|l|l|l|l|l|l|}
\hline 1 & $\begin{array}{l}\text { Moral leaders must be supportive and be willing to render } \\
\text { practical help to disorderly and the weak in dire } \\
\text { circumstances. }\end{array}$ & 6 & 2 & 18 & 6 & 41 & $\begin{array}{l}13 . \\
7\end{array}$ & 89 & 29.7 & 146 & $\begin{array}{l}48 . \\
7\end{array}$ \\
\hline 2 & $\begin{array}{l}\text { University leadership must be articulate enough to clarify } \\
\text { individual and group expectations. }\end{array}$ & - & - & 9 & 3 & 29 & 9.7 & 174 & 58 & 88 & $\begin{array}{l}29 . \\
3\end{array}$ \\
\hline 3 & $\begin{array}{l}\text { A good leader must develop the capacity to coach and } \\
\text { mentors' others. }\end{array}$ & - & - & 29 & 9.7 & 39 & 13 & 144 & 48 & 88 & $\begin{array}{l}29 . \\
3\end{array}$ \\
\hline 4 & $\begin{array}{l}\text { Inspiration leaders make combined use of both intrinsic } \\
\text { and extrinsic rewards to attract and retain employable } \\
\text { skills. }\end{array}$ & 26 & 8.7 & 48 & 16 & 41 & 13. & 39 & 13 & 146 & 48. \\
7 & $\begin{array}{l}\text { A moral leader with inspirational drive displays a deep } \\
\text { sense of humor and foresight to others. }\end{array}$ & 10 & 3.3 & 27 & 9 & 19 & 6.3 & 155 & 51.7 & 89 & $\begin{array}{l}29 . \\
7\end{array}$ \\
\hline 6 & $\begin{array}{l}\text { A good leader must develop the capacity to coach and } \\
\text { mentors' others. }\end{array}$ & - & - & 29 & 9.7 & 39 & 13 & 144 & 48 & 88 & $\begin{array}{l}29 . \\
3\end{array}$ \\
\hline 7 & $\begin{array}{l}\text { Inspiration leaders make combined use of both intrinsic } \\
\text { and extrinsic rewards to attract and retain employable } \\
\text { skills. }\end{array}$ & 26 & 8.7 & 48 & 16 & 41 & 13. & 39 & 13 & 146 & $\begin{array}{l}48 . \\
7\end{array}$ \\
\hline
\end{tabular}

\section{Shared values}

\begin{tabular}{|c|c|c|c|c|c|c|c|c|c|c|c|}
\hline & Questionnaire Items & \multicolumn{2}{|c|}{$\mathrm{U}(1)$} & \multicolumn{2}{|c|}{ SD (2) } & \multicolumn{2}{|c|}{$\mathrm{D}(3)$} & \multicolumn{2}{|c|}{ A (4) } & \multicolumn{2}{|c|}{ SA (5) } \\
\hline 1 & $\begin{array}{l}\text { Organisation must be committed to quality service } \\
\text { delivery }\end{array}$ & No & $\%$ & No & $\%$ & No & $\%$ & No & $\%$ & No & $\%$ \\
\hline 2 & $\begin{array}{l}\text { Organisational structure must support learning knowledge } \\
\text { sharing }\end{array}$ & - & - & - & - & 69 & 23 & 137 & 45.7 & 94 & $\begin{array}{l}31 . \\
3\end{array}$ \\
\hline 3 & Leaders must respect the right and conscience of others & 29 & 9.7 & - & - & 39 & 13 & 144 & 48 & 88 & $\begin{array}{l}29 . \\
3\end{array}$ \\
\hline 4 & People should be truthful and honest to each other & 26 & 8.7 & 48 & 16 & 41 & $\begin{array}{ll}13 . \\
6\end{array}$ & 39 & 13 & 146 & $\begin{array}{ll}48 . \\
7\end{array}$ \\
\hline 5 & Treat employees fairly as would want others treat you & 10 & 3.3 & 27 & 9 & 19 & 6.3 & 155 & 51.7 & 89 & $\begin{array}{l}29 . \\
7\end{array}$ \\
\hline 6 & $\begin{array}{l}\text { Organisation must promote culture that fosters career } \\
\text { progression }\end{array}$ & - & - & 9 & 3 & 29 & 9.7 & 174 & 58 & 88 & $\begin{array}{ll}29 . \\
3\end{array}$ \\
\hline 7 & Work-life balance will enhance quality of life & - & - & 29 & 9.7 & 39 & 13 & 144 & 48 & 88 & $\begin{array}{l}29 . \\
3\end{array}$ \\
\hline
\end{tabular}

Source: Analysis of Field Survey, 2020 